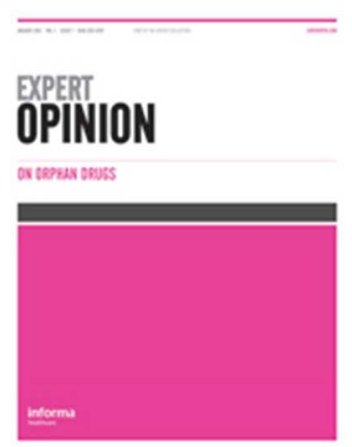

\title{
New insights in Primary Ciliary Dyskinesia
}

\begin{tabular}{|r|l|}
\hline Journal: & Expert Opinion on Orphan Drugs \\
\hline Manuscript ID & EOOD-2016-0143.R2 \\
\hline Manuscript Type: & Review \\
\hline Keywords: & $\begin{array}{l}\text { Clinical features, diagnostic methods, genetics, Primary Ciliary Dyskinesia, } \\
\text { therapy }\end{array}$ \\
\hline
\end{tabular}

\section{SCHOLARONE ${ }^{m}$}

Manuscripts 


\begin{abstract}
Introduction: Primary ciliary dyskinesia (PCD) is a rare genetic disease with an estimated prevalence of 1:20.000 births. It is characterized by abnormal motility of cilia, leading to impaired mucociliary clearance, and subsequent infection and chronic inflammation of the airways. PCD also affects spermatozoa and cilia in the Fallopian tubes, contributing to fertility issues; dyskinesia of embryonic nodal cilia causes a random distribution of the organs.
\end{abstract}

Areas covered: An overview of the history, genetics, clinical manifestations in children and adults, diagnostic tests, treatments, and prognosis are reviewed. We also discuss current research and future prospects of PCD.

Expert opinion: As PCD comprises defects in all organs with motile cilia, patients have a variety of clinical manifestations, often characterized by their presence from birth. Because of the non-specific symptoms, PCD is often confused with other diseases such as cystic fibrosis. There is no gold standard diagnostic test and a variety of diagnostic tests are required, including high-speed video analysis and transmission electron microscopy. Reanalysis following primary cultures of the epithelial cells can help to differentiate primary from secondary defects. Despite being a genetic disease, due to the genetic heterogeneity of PCD, gene analysis can currently only explain $65 \%$ of the cases. There is no treatment for PCD, and therapeutic options that contribute to the wellbeing of the patients are based on expert opinion.

\title{
KEYWORDS
}

Clinical features, diagnostic methods, genetics, Primary Ciliary Dyskinesia, therapy 


\section{ARTICLE HIGHLIGHTS}

- Primary Ciliary Dyskinesia (PCD) is a rare genetic disease characterized by abnormal mobility of motile cilia and sperm.

- The manifestations of PCD are characterized by their presence from birth, their persistent clinical course throughout life.

- The main clinical manifestations chronic infections in upper and lower airways, due to the inefficient mucociliary transport.

- The diagnosis of PCD lacks a "gold standard" and a combination of tests is therefore needed.

- Despite the existence of therapeutic options that contribute to wellbeing of patients, to date no specific treatment exists for PCD. 
1

2

3

4

5

6

7

8

9

10

11

12

13

14

15

16

17

18

19

20

21

22

23

24

25

26

27

28

29

30

31

32

33

34

35

36

37

38

39

40

41

42

43

44

45

46

47

48

49

50

51

52

53

54

55

56

57

58

59

60

\section{LIST OF ABBREVIATIONS}

PCD- Primary Ciliary Dyskinesia

CF- Cystic Fibrosis

COPD- Chronic Obstructive Pulmonary Disease

TEM- Transmission Electron Microscopy

CBP- Ciliary Beat Pattern

CBF- Ciliary Beat Frequency

HSVM- High Speed Video Microscopy

nNO- exhaled nasal Nitric Oxide

MCT- Mucociliary Transport

SCD- Secondary Ciliary Dyskinesia

PICADAR- the PrImary CiliAry DyskinesiA Rule

ALI- Air-Liquid Interface

ODA- Outer Dynein arms

IDA- Inner Dynein arms

HRCT- High-Resolution Computed Tomography

ODA-DC- ODA docking complex system

LCI- lung clearance index

QOL- quality of life

GCMCC- Genetic Disorders of Mucociliary Clearance Consortium

ERS- European Respiratory Society 


\section{Introduction}

Primary ciliary dyskinesia (PCD) is a rare genetic disease characterized by abnormal mobility of motile cilia. As a consequence, clearance of secretions, bacteria, pollutants and allergens is impaired from the upper and lower airways. PCD is the second most common congenital condition of the respiratory airways after cystic fibrosis (CF), with an estimated prevalence of 1/20.000 births (ORPHA244).

The main clinical manifestations are chronic symptoms and infections in upper and lower airways, due to the impaired mucociliary transport. Symptoms often start neonatally. During the infancy and childhood, the manifestations are daily wet cough, persistent rhinitis and serous otitis. Bronchiectasis can present in infancy, and by adulthood is almost universal[1]. PCD also affects spermatozoa and cilia in the Fallopian tubes, contributing to fertility issues. Moreover, dyskinesia of embryonic nodal cilia causes a random distribution of the organs, which produces situs inversus in $50 \%$ of the cases and situs ambiguous in $6 \%[2]$. The inheritance of PCD is autosomal recessive in the majority of the cases. In terms of genetics, PCD is a heterogeneous disease and to date mutations in 39 genes have been identified, accounting for $65 \%$ of PCD cases[3, 4].

Diagnosis of PCD is based on identifying the clinical manifestations, nasal Nitric Oxide (nNO) levels, analysis of the ciliary ultrastructure by Transmission Electron Microscopy (TEM), cilia function analysis by High Speed Video Microscopy (HSVM), and genetic testing [5]. However, the heterogeneity of the disease and the similarities with other chronic respiratory diseases often cause delay in the diagnosis.

To date no specific treatment exists for PCD. However, therapeutic options that contribute to wellbeing include regular monitoring of respiratory and auditory function, regular airway clearance of secretions through physiotherapy and physical exercise, and the use of antibiotics for treating airways infections[1]. 


\section{Historical Background.}

The association of situs inversus and bronchiectasis was first described by Siewert in 1901 and published shortly after in 1904 [6]. In 1933, Kartagener described a group of patients who presented with bronchiectasis, sinusitis and situs inversus[7] leading to the term"Kartagener's syndrome".

In 1975, Afzelius identified ultrastructural abnormalities in the spermatozoa of a group of infertile men who had also chronic bronchiectasis[8]. Subsequent studies showed that these patients had similar ultrastructural alterations in their respiratory cilia[9]. Moreover, in 1977 Elliasson described a group of patients presenting with similar symptoms and ultrastructural abnormalities, but no situs inversus[10]. Therefore, since 1980 the term "immotile cilia syndrome" was coined, reserving "Kartagener syndrome" to define the triad of sinusitis, bronchiectasis and situs inversus[11, 12].

In 1988, Rossman and Newhouse demonstrated that symptoms may be due not only to the total immobility of cilia, but also to dyskinetic and inefficient movement. Therefore, the term PCD was proposed instead of "immotile cilia syndrome"[13].

During late $80^{\prime} \mathrm{s}$ it was shown that mucociliary transport could be altered not only by inherited ultrastructural defects of cilia, but also by factors such as recurrent viral or bacterial infections, resulting in ciliary dysfunction that could reproduce the clinical picture of the PCD $[14]$.The name "secondary ciliary dyskinesia (SCD)" was used to refer to the transient alteration of mucociliary transport, as opposed to PCD which refers to its hereditary and permanent character [15].

Recent advances in HSVM and in genetics have further opened our understanding of disease, such that the term 'primary ciliary dyskinesia' is probably inadequate to describe all variants, for example, some patients have reduced numbers of motile cilia.

\section{Clinical manifestations in children.}


The manifestations of PCD are characterized by their presence from birth, their persistent and progressive clinical course throughout life, simultaneously affecting all organs in which the motile cilia exert their function (Table 1).

Diagnosis of PCD is frequently delayed $[16,17]$, in part because patients present with symptoms (rhinitis, secretory otitis media, cough and recurrent bronchitis) that are common in the non-PCD population. A recent systematic review aimed to investigate how symptoms of PCD vary by age, but reported that most studies were small, with poor stratification by age [18].

Approximately $40-55 \%$ of affected patients have situs inversus and 6-12\% have heterotaxy (situs ambiguus), which can be associated with cardiac defects[19, 20]. Mild fetal cerebral ventriculomegaly could be an early sign of $\mathrm{PCD}[21]$, perhaps related to ependymal ciliary dysfunction, and hydrocephalus is a very rarely reported [18].

PCD usually presents with unexplained neonatal respiratory distress (75-85\%)[22]. Symptoms start after a few hours of life and often need prolonged supplemental oxygen[23]. Lobar collapse of the upper and middle lobe is a frequent complication in the neonatal period. This is in contrast to older children and adults with PCD where radiological findings typically involve the middle and lower lobes.

Chronic nasal congestion and daily wet cough are common features throughout life [18, 24]. Symptoms might partially improve with antibiotic therapy or changes of season, but do not resolve completely $[23,25]$.

Chronic or recurrent otitis media with effusion is very common and is often associated with conductive hearing difficulty. Persistent otorrhoea can occur after ventilation tube insertion. Symptoms of sinusitis often develop in childhood. However, nasal polyposis is rare in children $[1,26]$.

\section{Clinical manifestations in adults.}


Daily wet cough and chronic rhinorrhea persist into adulthood. Rhinitis responds poorly to standard treatments and is often complicated by sinusitis in older children and adults. Nasal polyposis is said to be less common than in CF. Ear problems generally improve with age, but patients may have permanent conductive hearing loss [27]

PCD patients often have hypoplasia of the paranasal sinuses, and especially, frontal sinus aplasia (Figures 1B and 1C: Radiological typical findings in an adult patient with PCD), evidenced when performing a computed tomography scan (CT).

Although bronchiectasis can appear in infancy, it is almost universal by adulthood. Cylindrical or saccular bronchiectasis involves the middle and lower lobes (Figure 1A) and the lingula. In addition, patients typically have radiological findings of peribronchial thickening, atelectasis and air-trapping [28, 29].

Patients often have poor pulmonary function, ranging from mild to severe as a consequence of recurrent and chronic infection [30, 31].

Fertility problems are apparent in some adults. Some men have alive but immotile sperm, making them infertile. Impaired ciliary function in the fallopian tubes delays ovum transport which might cause infertility. However some patients are fertile [32], and good studies are needed to understand the true prevalence of infertility[33]. There have been very rare reports of ectopic pregnancy in patients with PCD but it is not clear if it is more common than in the general population[34, 35].

\section{Diagnosis and treatment of PCD.}

\subsection{General considerations}

The diagnosis of PCD lacks a "gold standard" and a combination of tests is therefore needed to get a conclusive diagnostic. A European Respiratory Society Task Force has recently published evidence-based guidelines for making or excluding the diagnosis [36]. 
The first step is identifying patients with a compatible clinical history for diagnostic testing. Two studies propose screening tools based on symptom scores [24, 37]. PICADAR was developed using symptom data from $>600$ patients referred for diagnostic testing [24]. A regression model identified symptoms that were predictive of PCD for inclusion in the 7-item clinical tool (27). Another study developed a predictive score based on 4 clinical symptoms, demonstrating that by using 'enhanced questions' (e.g. "early onset year-round wet cough" rather than simply "wet cough") the specificity improved, but sensitivity reduced [37].

Clinical manifestations of PCD are similar to other diseases such as CF, immunodeficiency, Aspergillus or Tuberculosis infections, chronic gastro-esophageal reflux with aspiration, and alpha-1 antitrypsin deficiency[38]. Some of these conditions have conclusive diagnostic tests that could be considered before starting with PCD diagnostic tests.

\subsection{Diagnostic tests}

\subsection{1 nNO levels}

$\mathrm{nNO}$ is the recommended initial test in symptomatic patients[36, 40$]$ and low levels of nNO should prompt referral for further tests. Despite having a good sensitivity, a small number of PCD patients have normal nNO levels so full diagnostic testing should not be prevented if the clinical suspicion is high[36], and low nNO levels are also associated with other similar pathologies as CF. Although it can contribute to the final diagnostic decision, $\mathrm{nNO}$ cannot be used as a conclusive tool because of false positive and false negative cases[5]. Moreover, it cannot be applied to children $<6$ years old.

\subsubsection{Study of ciliary beat pattern and ciliary beat frequency}

Study of ciliary mobility by HSVM has good sensitivity and specificity [36, 41]. Analysis should be conducted by experienced personnel and requires sophisticated equipment. Differentiating primary and secondary causes of PCD can be extremely difficult; repeating 
the HSVM following culture at an air-liquid interface (ALI) cell cultures, can help with the distinction $[36,42]$.

\subsubsection{Genetic tests}

Approximately $65 \%$ of patients have mutations in one of the 39 known PCD genes. Current guidelines suggest that genetics testing is directed by other diagnostic tests [36] but as knowledge of genetic mutations improves, genotype is likely to take a more prominent role in diagnostic algorithms. There are genotypes which are difficult to diagnose by other tests where genetics testing already has an important role e.g. mutations in CCNO and RSPH4 (See section PCD genetics).

\subsubsection{Transmission Electronic Microscopy}

TEM allows study of the ciliary axoneme. The most common ultrastructure defects that cause ciliary movement abnormalities are: outer dynein arm (ODA) -defects (25-50\%), combined ODA and inner dynein arms (IDA) deffects (25-50\%), IDA defects associated with microtubular disorganization (15\%) and central microtubule pair defects $(5-15 \%)[36,43,44]$. The pathogenicity of isolated IDA is controversial. Central pair defects are characterized by a mix of both normal and abnormal cilia necessitating protocols that count a large number of cilia in cross section (e.g. $>100$ ) to ensure that false negatives are avoided.[45]. Moreover, some defects cannot be detected by classical TEM in 15-20\% of PCD patients [36]. Despite limitations with TEM, this test is excellent for confirming PCD in patients with 'hallmark' ultrastructural defects (Figures 2A, 2B and 2C) [36].

\subsubsection{Differentiated airway epithelial cells cultures}

Chemical and biological agents (e.g. viruses and bacteria) can alter ciliary activity, disturbing the mucus clearance and leading to pulmonary damage. It can be difficult to discriminate SCD from PCD by HSVM, making diagnosis difficult if TEM and genetics tests are normal. In these cases, it is informative to culture the nasal epithelial cells obtained from the initial 
brushing using an ALI technique [42] repeating the HSVM in those re-differentiated cells: if ciliary dyskinesia is secondary, the ciliary activity of re-differentiated cells will be normal, but if it is due to PCD, ciliary dyskinesia will persist in the cultured cells [36, 42].

\subsubsection{Immunofluorescence analysis of cilia proteins}

Immunofluorescence staining of specific ciliary structure proteins is a potential diagnostic test. However, to date there have been no studies investigating its role as a diagnostic test. [46]

\subsection{Treatment of PCD}

Currently, there is no specific treatment to restore ciliary mobility. Therefore, management is usually based on evidence from other more common disorders e.g. CF and rhinosinusitis.

Firstly, it is necessary to monitor airways disease, upper airways symptoms and audiology. Consensus guidelines recommend that treatment is based in combinations of antibiotics and airway clearance therapies[46, 47]. Airway clearance should be improved by regular chest physiotherapy and physical exercise, anecdotally providing important benefits for patients[48]. It is important to treat infections tailoring medication to sputum cultures. An international trial is currently investigating the role of azithromycin to prevent exacerbations.[49] To treat Pseudomonas colonization, management is usually extrapolated from CF. Whereas mild exacerbations are often treated with oral antibiotics and physiotherapy, severe or refractory exacerbations require intravenous antibiotics[50].

The role of agents such as hypertonic saline or mannitol, recombinant deoxyribonuclease, Nacetylcisteine or anti-inflammatory treatments remain unclear in PCD patients[48, 51]. Bronchodilators and inhaled corticosteroids should be considered in patients with PCD who also have co-existing asthma or bronchial reversibility, but are not indicated routinely[48]. 
Infection prevention is recommended in PCD patients, so routine vaccines, as well as all PCD patients should receive routine immunizations plus Pneumococcal and Influenza vaccinations $[48,52,53]$.

Chronic rhinorrhea might be helped by sinus rinses. Rhinosinusal superinfections are treated with antibiotics. Surgical treatment of rhinosinusitis is controversial. Treatment of secretory otitis media by timpanostomy is also controversial particularly as it may be complicated by prolonged postoperative chronic otorrhea, therefore conservative management is usually advocated. The periodic use of hearing aids is often recommended by experts $[54,55]$.

In severe cases of PCD with end stage lung disease, lung transplantation may be an option[56]. Surgical resection remains controversial[57]. Cardiac defects are 200-fold higher in PCD than in general population[19]. The spectrum of cardiac defects is wide and management depends on the lesion[58]. Careful pre-operative planning by a multidisciplinary team of cardiologists, pulmonologists and intensivists is needed, since the post-operative course is often complicated.

Genetic counselling and management should be offered to patients that want to have children, considering that is an inherited disease. Intracytoplasmic spermatozoa injections could facilitate conception in males with immotile sperm[33]. In addition, in vitro fertilization and intra-uterine implantation could help female patients with PCD with decreased fertility[59].

\section{Evolution and prognosis.}

The literature regarding longitudinal lung function in adult and pediatric PCD is conflicting; studies show stability in lung function over time, wide variability or steady deterioration. Some reports [60-62] have indicated that lung function can be stabilized after diagnosis and initiated treatment, even in patients with late diagnosis and poor lung function. However, a study of 74 PCD patients showed a great variation in the course of lung function following 
diagnosis [30] with pulmonary function remaining stable in $>50 \%$, deteriorating in one third, and improving in others. Pulmonary function was already impaired at the first spirometric measurement in more than one-third of children with preschool PCD diagnosis demonstrating that early diagnosis does not always protect against impaired lung function, and that PCD is a disease of serious threat to lung function even at preschool age.

Despite widespread use, there is no evidence that lung function alone is useful in the assessment of progression of lung disease in PCD. Imaging techniques like high-resolution computed tomography (HRCT) can be more sensitive. In one study spirometry was less accurate than HRCT in detecting changes associated with progression of lung disease; structural damage worsened despite stable spirometry, and longitudinal evolution of FEV1 was not significantly associated to the change in HRCT total score[63]. In a recent pediatric cohort study, moderate lung function worsening, progressive structural lung impairment detected by HRCT and a significant correlation between HRCT score and FEV1 decline were reported [64]. Adult PCD studies have also shown that HRCT severity scores are associated with disease progression with a very high frequency of bronchiectasis $(96-100 \%)[28,65]$.

There is little information about the evolution of PCD into adult life. Even data on mortality is extremely limited. In a large British clinic, the median age at death was 65 years (range 3175 years) and no patients underwent lung transplant [65]. In an American cohort $38 \%$ of adults experienced respiratory failure and had an FEV1 $\leq 40 \%$ with some patients having or being considered for lung transplantation[31]. Bilateral lung transplantation for end-stage PCD is probably rare in Europe.

There is not much knowledge about features associated with disease progression in PCD. Isolation of Pseudomonas aeruginosa has been associated with increased severity of disease and mortality in $\mathrm{CF}$ and in adult non-CF bronchiectasis. In PCD P. aeruginosa colonization seems to be a marker of disease severity reflecting cases with more impaired FEV1 and 
higher radiological extent of bronchiectasis, but it is not associated with longitudinal decline of FEV1[65].

Ciliary ultrastructure and the type of genetic mutations could be related to prognosis Microtubular defects (CCDC39, CCDC40) and CCNO mutations have been suggested to be associated with a more severe phenotype. This needs confirming through large collaborative studies. $[23,65]$

\section{Genetics of PCD.}

PCD is a Mendelian autosomal recessive and genetically heterogeneous disorder (with the exception of two rare X-linked syndromic genes, RPGR (MIM 312610) and OFD1 (MIM 300170), which combine PCD with retinitis pigmentosa and orofacial digital syndrome, respectively, and PIH1D3 (MIM 300933), an X-linked gene causing non-syndromic PCD. For autosomal recessive causes, pathogenic mutations must be find on bi-allelic genes. No documented cases of heterozygous mutations in two different PCD genes have been associated with human PCD.

There are currently 39 known genes associated with PCD (Table 2), with new genes being discovered at a rapid pace. These gene-mutations account for only $60-70 \%$ of individuals affected with PCD. Of the 39 known genes, 10 encode proteins of the ODAs or the ODA docking complex system (ODA-DC) (DNAH5 [MIM 603335; 15-21\% prevalence], DNAH11 [MIM 603339; 6\% prevalence], CCDC114 [MIM 615038], TTC25 [MIM 617095], DNAL1 [MIM 610062], DNAI1 [MIM 604366], DNAI2 [MIM 605483], NME8 [MIM 607421], ARMC4 [MIM 615408] and CCDC151 [MIM 615956 ]) mutations of which generally cause isolated outer dynein arm deficiency. PCD mutations in genes controlling ODA complex protein generally are translated in immotile cilia phenotype, since ODA controls effective movement of cilia. Eleven genes encode cytoplasmic proteins involved in assembly and transport of the dynein arms into axonemes (SPAG1 [MIM 603395], DNAAF1 
[MIM 613190], DNAAF2 [MIM 612517], DNAAF3 [MIM 614566], HEATR2 [MIM 614864], DYX1C1 [MIM 608706], ZMYND10 [MIM 607070], DNAH1 [MIM 603332], LRRC6 [MIM 614930], CCDC103 [MIM 614677] and C21orf59 [MIM 615494]) mutations of which combine ODA and IDA deficiency.

Thirteen genes with PCD causal mutations are associated factors of the N-DRCs, including CP, RS, CP and MT (N-DRC regulators CCDC39 [MIM 613798], CCDC40 [MIM 613799], CCDC65 [MIM 611088], CCDC164] [MIM 615288]) and GAS8 [616726]; RS regulators (RSPH1 [MIM 609314], RSPH4A [MIM 612647], RSPH3 [MIN 616481], DNAJB13 [MIM 610263] and RSPH9 [MIM 612648]); CP microtubules (HYDIN [MIM 610812]; regulators of multi-ciliated cell differentiation and ciliogenesis CCNO [MIN 615872] and MCIDAS, which loss results in a reduction in the number of motile cilia) which cause defects in cilia movements but not immotile cilia. More recent studies added new gene defects that affect to energy regulatory proteins of cilia such as adenylate kinase 7 (AK7) mutation in PCD subjects[66].

Gene therapy is an area of interest. In a proof of principal study gene editing using transcription activator-like effector nucleases (TALENs) corrected a DNAh11 mutation in an ex vivo model[67]. Other promising gene edition repair strategies include clustered regularly interspaced short palindromic repeats (CRISPRs). However, delivery to cells in humans, offtarget effects and unintended DNA cleavage, inter- and intra-chromosomal rearrangements and variable DNA cleavage efficiencies may limit the rapid progression of PCD gene repair.

\section{On-going research and future prospects.}

Basic Science: Since Afzelius and Pedersen proposed the unifying role of cilia to explain the syndrome in 1976, basic scientists have developed our understanding of the underlying pathophysiology and genetics of PCD. The first PCD-causing gene was described in 1999 [68] and there are now over thirty known genes. As previously discussed, personalized 
treatments targeting specific genetic defects, have become a recent area of interest. Further advances to characterize and correct mutations or protein function will require pre-clinical models including human ex vivo and animal in vivo models. Animal models have been pivotal to our understanding of the diverse aspects of biology in motile cilia; these include molecular composition, mode of assembly, motility mechanisms, PCD pathogenesis and PCD candidate gene identification. Cilia and flagella have been conserved through much of evolutionary history, and models which have been used to develop our understanding of PCD include invertebrate systems such as Chlamydomonas reinhardtii [69-71] and vertebrate models such as Xenopus [72, 73] and zebra fish[74-76]. Genetic PCD mice are the only models with lungs, and while displaying aspects of human PCD such as rhinitis and laterality defects, they do not develop significant chest disease despite immotile respiratory cilia; importantly most but not all genetic backgrounds have the potential to develop severe morbidity from hydrocephalus with differences in expressivity and/ or penetrance dependent on the background strain [77-80]. The power of these various models in cilia research has been explored in a number of outstanding review manuscripts[79, 81-83].

Epidemiology: Most epidemiological research on PCD come from small datasets. A recent systematic search found 50 publications with clinical information[18] and reported that data quality was often poor, results were not age-stratified and populations were highly selected from specialist clinics. Only a few studies have described longitudinal data, such as changes of lung function[84, 85] or growth [85] over time. Collaborations between multiple centers are starting to provide into insights to gene-phenotype associations, with a suggestion that CCDC39/ CCDC40 are associated with more severe lung disease[23].

Diagnostic testing: There are considerable differences between centers and countries with respect to diagnostic testing, $[45,86,87]$ which is not surprising given the lack of a 'gold standard'. A number of studies have investigated the accuracy of established tests to diagnose 
PCD including HSVM [41, 88], TEM [41, 89-93], reanalysis following cell culture [42, 94] and genetics testing $[23,95]$. Major difficulties for interpreting these accuracy studies include the lack of a reference standard, and no global standardization of methods. Explorations to improve diagnostic accuracy in 'difficult cases', where TEM is normal and pathogenic mutations have not been identified, have included electron tomography [96, 97] and radioaerosol mucocilary clearance [98, 99]. Electron tomography is an advanced EM technique used for the visualisation of structures in 3D. Resolution of approximately $5 \mathrm{~nm}$ and the $3 \mathrm{D}$ information have been used to provide important insights into the structure of molecules and their interactions within the axoneme of Chlamydomonas reinhardtii, and more recently to confirm the absence of Hydin or DNAh11 molecules as causes of PCD $[100$, 101]. This has led to an interest in the potential of electron tomography as a diagnostic tool in patients with apparently normal ultrastructure by standard TEM[100].

Treatment and outcome measures: To date there have been no powered randomized trials to guide choice of treatments, therefore clinical management varies widely [87]. An international trial is currently investigating the role of azithromycin to reduce pulmonary exacerbations [49], and a further study is investigating the effect of sodium channel inhibition on lung function (https://clinicaltrials.gov/ct2/show/NCT02871778). One of the obstacles to clinical trials has been lack of reliable and responsive outcome measures. Spirometry has the disadvantage of declining slowly in most PCD patients[84, 102], it cannot be measured in young children and infants, and it is insensitive to structural disease evident on high resolution CT-imaging[103]. High resolution CT is sensitive to lung damage but is not suitable for repeated measures because of the radiation exposure. In recent years there has been renewed interest in lung clearance index (LCI) measured by multiple-breath washout in $\mathrm{CF}$, and several studies have now been conducted in PCD. LCI is more sensitive than spirometry in PCD [104-107] and can be used in infants and young children. We need 
longitudinal data, and standardized methods before LCI can be secured as an outcome measure for PCD clinical trials[107, 108].

Patient reported outcome measures are advocated for clinical trials to assess the impact disease has on the patient's daily functioning; the QOL-PCD are age-appropriate healthrelated quality of life measures. These tools were developed in the English language to be linguistically and culturally equivalent in North America and Europe[109, 110]. Validation studies have confirmed reliability of QOL-PCD, and the instruments have been translated into a number of languages[111]. This international approach is important for rare diseases since multi-national clinical trials will enable recruitment of sufficient patients.

Research collaborations: Over recent years, advances in the field of PCD have occurred through separate collaborations of clinicians and of scientists. Several international initiatives have stimulated these advances including the North American Genetic Disorders of Mucociliary Clearance Consortium (GDMCC)[23, 112-114], Ciliopathy Alliance, Gordon Conferences, two network European Respiratory Society (ERS) Task Forces[16, 36, 87, 115, 116] and European FP7-funded BESTCILIA [49, 109, 117]. To maintain the momentum of these collaborations and to build on their successes, there was a need for networks to bring clinicians and scientists together. BEAT-PCD (http://www.beatpcd.org/) is a collaboration supported by EU- Framework Horizon 2020 (COST Action BM1407). The global network includes experts from diverse clinical specialties (e.g. pediatric \& adult pulmonology, ENT, physiotherapy) and multidisciplinary scientists (e.g. genetics, imaging, cell biology, microbiology, and bioinformatics). They aim to identify gaps in knowledge, and then facilitate PCD-related research to identify mechanisms, study disease patterns and progression, define outcome measures, improve clinical management and identify high priority therapies. In the United States, the PCD Foundation (http://www.pcdfoundation.org/) 
is promoting the advance of PCD through annual conferences, community education, patient advocacy, and research funding.

In summary, PCD research is gathering momentum through successful collaborations, but many questions remain unanswered in this exiting research arena.

\section{Conclusion.}

In conclusion, PCD is a congenital disorder that affects upper and lower airways. Clinical manifestations can vary depending on the patient and their age. As a consequence of the variety of manifestations and the similarities between PCD and other chronic respiratory diseases, patients fail to be referred for diagnostic testing. There is no gold standard diagnostic test, and a combination of nNO levels, analysis of cilia ultrastructure by EM; analysis of ciliary function by HSVM, and genetic testing can be used [36]. Because there are a large number of implicated genes and mutations, and because many genes have yet to be found, genetic testing is far from being a definitive diagnostic method for PCD. Moreover, with a lack of specific treatments, management is limited to careful monitoring, physiotherapy and physical exercise, as well as the use of antibiotics to treat the infections. The lack of a definitive diagnostic test and absence of specific treatments highlight the relevance of research in this area. Expert multidisciplinary reference centres working together through international networks are promoting advances in diagnostic and clinical management (http://ern-lung.org/ and GDMCC).

\section{Expert opinion}

Cilia disorders are known as ciliopathies. Ciliopathies of the primary cilia are responsible for diverse sensorial syndromes and deficits, such as disorders of smell (anosmia), hearing (sensorineural hearing loss), and vision (retinal degeneration). Primary ciliopathies are also responsible for conditions such as polycystic kidney, polydactyly, central nervous system malformations, developmental delay, heart, gonadal and craniofacial malformations, as well 
as basal carcinomas. These features can occur in various combinations in a patient, leading to syndromes such as Usher (hearing and vision loss), Bardet Biel, Alstrom, Joubert, Merckel Gruber, Senior Locken syndrome, and probably others that still unknown. PCD is a ciliopathy caused by abnormal motile (rather than primary) cilia. Association of motile and primary ciliopathies in the same patient are unusual.

PCD includes a heterogeneous group of genetic disorders. This heterogeneity is related with a variety of phenotypes, including different abnormal patterns of ciliary structure and function. Consequently, diagnostic testing can be a challenge. A definitive diagnosis is essential, mainly for the patient's care, but also for recruitment to research studies.

Children with chronic respiratory infections that appear from birth, simultaneously affecting upper and lower airways, with little or no improvement at any time of the year are highly suspicious of PCD. Newborns with no identifiable cause of neonatal respiratory disease, with or without organic laterality disorder are highly suspicious of PCD if symptoms persist. It is important that physicians are aware of the symptoms of PCD, and that they refer appropriate patients for diagnostic testing.

To diagnose PCD patients, having a strong clinical history (including nNO levels if it is possible), the starting point is HSVM analysis of the ciliary function, followed by TEM analysis of the ciliary structure. In case of poor health of the initial sample, ALI primary cultures of nasal or bronchial epithelial cells can be done, and ciliary function and structure re-analysed in order to differentiate primary from secondary defects. Sometimes it is necessary to repeat the sampling and tests, especially the motility studies. These tests are complex and it is essential that the studies are carried out by experts.

The complexity of the diagnostic tests has led to development of reference centers, with specialist in PCD professionals. These specialist centers are expensive and require funding. The difficulties caused by lack of a gold standard test, the necessity of specialists to carry out 
the diagnostic tests, and the funding these services require has led to differences in provision between countries.

Clinical management of these patients requires lifetime medical care. The treatment should be adapted to the clinical evolution, whereas respiratory physiotherapy is needed daily. Treatment with antibiotics is often needed, and should be adapted according to the patient's clinical status and microbiological studies. Otitis media with effusion is common in patients with PCD, leading to recurrent acute otitis media, hearing loss, and potentially chronic suppurative otitis media even with cholesteatoma. Therefore, in some cases surgical treatment is necessary. In children with hearing loss, hearing aids should be considered to prevent speech delay and educational compromise.

In terms of new therapies, there are currently clinical trials with inhaled solution of epithelial sodium channel inhibitors in subjects with PCD investigating the effect on pulmonary function. Because of the genetic heterogeneity that characterises PCD, gene therapy is more difficult to achieve than in monogenic diseases. However, gene therapy focused in the most prevalent and better described mutations could be a reality providing a definitive curation of patients with specific mutations.

In spite of what we have learnt to date, basic and clinical aspects of the disease remain poorly understood. The prevalence and severity of clinical symptoms and how these vary with age, sex, and country are not known. there is poor data about progression of disease over time, mortality and evolution of lung function. Moreover, there is a lack of prognostic factors, which could be useful for the clinical management of PCD patients. Finally, genotyping can only explain around $65 \%$ of PCD cases, so further research is needed to detect further causative genes. 


\begin{tabular}{|c|c|c|c|c|c|}
\hline PCD genes & $\begin{array}{l}\text { Prevalence } \\
\text { in PCD }\end{array}$ & $\begin{array}{l}\text { Protein } \\
\text { localization/ } \\
\text { function }\end{array}$ & $\begin{array}{l}\text { Ciliary } \\
\text { ultrastructure } \\
\text { defect }\end{array}$ & $\begin{array}{l}\text { Phenotypic } \\
\text { presentation }\end{array}$ & Ref. \\
\hline DNAH5 & ++++ & ODA & ODA defect & Immotile cilia & $\begin{array}{l}{[118-} \\
120]\end{array}$ \\
\hline DNAI1 & +++ & ODA & ODA defect & Immotile cili & $\begin{array}{l}{[121-} \\
125]\end{array}$ \\
\hline DNAI2 & ++ & ODA & ODA defect & Immotile cilia & {$[126]$} \\
\hline DNAL1 & + & ODA & ODA defect & $\begin{array}{l}\text { Impaired } \\
\text { motility }\end{array}$ & {$[127]$} \\
\hline CCDC114 & ++ & $\begin{array}{l}\text { ODA docking } \\
\text { complex }\end{array}$ & ODA defect & Immotile cilia & $\begin{array}{l}128, \\
129]\end{array}$ \\
\hline TTC25 & + & $\begin{array}{l}\text { ODA docking } \\
\text { complex }\end{array}$ & ODA defect & Immotile cilia & {$[130]$} \\
\hline CCDC 151 & ++ & $\begin{array}{l}\text { ODA targeting } \\
\text { and docking }\end{array}$ & ODA defect & Immotile cilia & $\begin{array}{l}{[131,} \\
132]\end{array}$ \\
\hline ARMC4 & ++ & $\begin{array}{l}\text { ODA docking } \\
\text { complex }\end{array}$ & ODA defect & Immotile cilia & $\begin{array}{l}133, \\
134]\end{array}$ \\
\hline CCDC103 & ++ & $\begin{array}{l}\text { Cytoplasmic, } \\
\text { ODA assembling }\end{array}$ & $\mathrm{ODA} \pm$ defect & Immotile cilia & {$[135]$} \\
\hline $\begin{array}{l}\text { NME8 } \\
\text { (TXNDC3) }\end{array}$ & + & ODA & $\begin{array}{l}\text { Partial ODA } \\
\text { defect }\end{array}$ & Immotile cilia & {$[136]$} \\
\hline $\begin{array}{l}\text { DNAAF1 } \\
(\text { LRRC50) }\end{array}$ & ++ & $\begin{array}{l}\text { Cytoplasmic, } \\
\text { DA assembling }\end{array}$ & $\begin{array}{l}\text { ODA and IDA } \\
\text { defects }\end{array}$ & Immotile cilia & $\begin{array}{l}{[137,} \\
138]\end{array}$ \\
\hline DNAAF2 & ++ & Cytoplasmic, & ODA and IDA & Immotile cilia & [139] \\
\hline
\end{tabular}




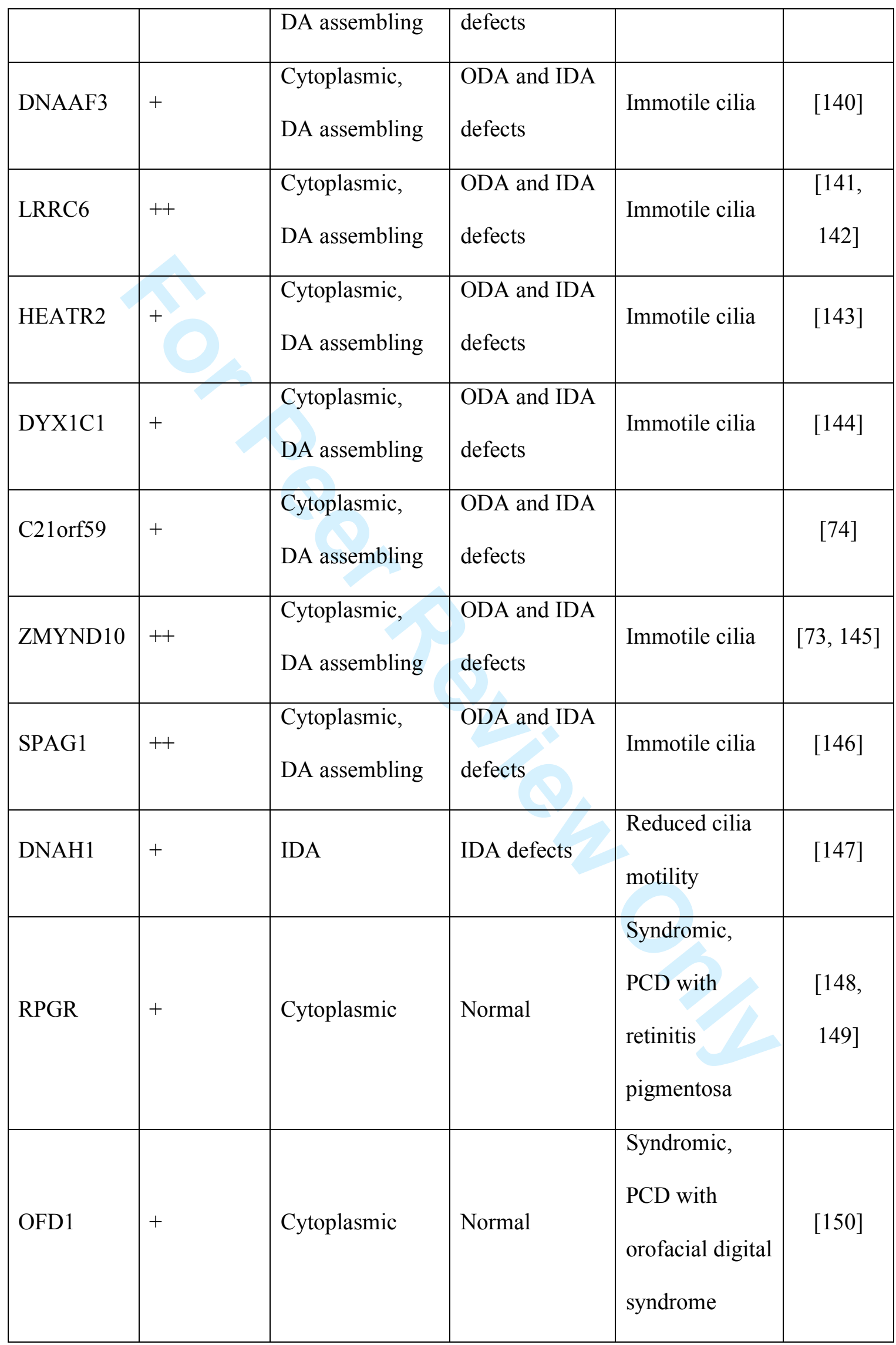




\begin{tabular}{|c|c|c|c|c|c|}
\hline PIHID3 & + & Cytoplasmic & $\begin{array}{l}\text { ODA and IDA } \\
\text { defects }\end{array}$ & $\begin{array}{l}\text { Mostly } \\
\text { immotile }\end{array}$ & {$[151]$} \\
\hline DNAH11 & +++ & ODA & Normal & $\begin{array}{l}\text { Hyperkinetic } \\
\text { cilia, reduced } \\
\text { amplitude }\end{array}$ & $\begin{array}{l}{[152,} \\
153]\end{array}$ \\
\hline HYDIN & + & $\begin{array}{l}\text { Central pair } \mathrm{C} 2 \mathrm{~b} \\
\text { defect with } \\
\text { normal body } \\
\text { composition }\end{array}$ & Normal & $\begin{array}{l}\text { Reduced } \\
\text { amplitude, } \\
\text { discoordination }\end{array}$ & {$[154]$} \\
\hline $\begin{array}{l}\text { CCDC164 } \\
(\mathrm{DRC} 1)\end{array}$ & + & $\begin{array}{l}\text { Nexin-dynein } \\
\text { regulatory } \\
\text { complex defect }\end{array}$ & $\begin{array}{l}\text { Mostly } \\
\text { normal/with } \\
\text { DRC defects }\end{array}$ & $\begin{array}{l}\text { Reduced } \\
\text { bending } \\
\text { amplitude }\end{array}$ & {$[70]$} \\
\hline $\begin{array}{l}\text { CCDC65 } \\
(\mathrm{DRC} 2)\end{array}$ & + & $\begin{array}{l}\text { Nexin-dynein } \\
\text { regulatory } \\
\text { complex defect }\end{array}$ & Mostly normal & $\begin{array}{l}\text { Impaired } \\
\text { motility }\end{array}$ & [74] \\
\hline GAS8 & + & $\begin{array}{l}\text { Nexin-dynein } \\
\text { regulatory } \\
\text { complex defect }\end{array}$ & Mostly normal & $\begin{array}{l}\text { Reduced } \\
\text { bending } \\
\text { amplitude }\end{array}$ & {$[155]$} \\
\hline CCDC39 & +++ & $\begin{array}{l}\text { Nexin-dynein } \\
\text { regulatory } \\
\text { complex defect } \\
\text { and IDA } \\
\text { assembling }\end{array}$ & $\begin{array}{l}\text { MT } \\
\text { disorganisation } \\
\text { and IDA defect }\end{array}$ & $\begin{array}{l}\text { Hyperkinetic, } \\
\text { stiff cilia }\end{array}$ & $\begin{array}{l}{[156,} \\
157]\end{array}$ \\
\hline CCDC40 & +++ & $\begin{array}{l}\text { Nexin-dynein } \\
\text { regulatory }\end{array}$ & $\begin{array}{l}\text { MT } \\
\text { disorganisation }\end{array}$ & $\begin{array}{l}\text { Hyperkinetic, } \\
\text { stiff cilia }\end{array}$ & $\begin{array}{l}156, \\
158]\end{array}$ \\
\hline
\end{tabular}




\begin{tabular}{|c|c|c|c|c|c|}
\hline & & $\begin{array}{l}\text { complex defect } \\
\text { and IDA } \\
\text { assembling }\end{array}$ & and IDA defect & & \\
\hline RSPH9 & + & Radial spoke & $\begin{array}{l}\text { MT } \\
\text { disorganisation } \\
\text { (CP-RS defect) }\end{array}$ & Circular beat & $\begin{array}{l}{[159-} \\
161]\end{array}$ \\
\hline RSPH4A & ++ & Radial spoke & $\begin{array}{l}\text { MT } \\
\text { disorganisation } \\
\text { (CP-RS defect) }\end{array}$ & $\begin{array}{l}\text { Circular beat or } \\
\text { stiff cilia }\end{array}$ & $\begin{array}{l}{[159-} \\
161]\end{array}$ \\
\hline RSPH1 & ++ & Radial spoke & $\begin{array}{l}\text { MT } \\
\text { disorganisation } \\
\text { (CP-RS defect) }\end{array}$ & $\begin{array}{l}\text { Different } \\
\text { beating patterns }\end{array}$ & $\begin{array}{c}{[160,} \\
162,163]\end{array}$ \\
\hline RSPH3 & + & Radial spoke & $\begin{array}{l}\text { MT } \\
\text { disorganisation } \\
\text { (CP-RS defect) }\end{array}$ & $\begin{array}{l}\text { Reduced } \\
\text { bending } \\
\text { amplitude }\end{array}$ & [164] \\
\hline DNAJB13 & + & $\begin{array}{l}\text { Radial } \\
\text { spoke/cytoplasm }\end{array}$ & $\begin{array}{l}\text { Abnormal } \\
\text { percentage of } \\
\text { cilia lacking } \\
\text { central } \\
\text { microtubules }\end{array}$ & Inmotile & [165] \\
\hline $\mathrm{CCNO}$ & + & $\begin{array}{l}\text { Apical } \\
\text { cytoplasm }\end{array}$ & $\begin{array}{l}\text { Oligocilia } \\
\text { (residual } \\
\text { axoneme } \\
\text { normal) }\end{array}$ & $\begin{array}{l}\text { Reduction of } \\
\text { multiple motile } \\
\text { cilia }\end{array}$ & {$[166]$} \\
\hline MCIDAS & + & Apical & Oligocilia & Reduction of & [72] \\
\hline
\end{tabular}




\begin{tabular}{|l|l|l|l|l|l|}
\hline & & cytoplasm & (residual & multiple motile & \\
& & & axoneme & cilia & \\
\hline DNAH8 & + & Not available & & {$[167]$} \\
\hline AK7 & + & Cytoplasm & Normal & Reduced ciliary & {$[66]$} \\
\hline
\end{tabular}

Table $2:+$, genetic mutations causing $<1 \%$ of all $\mathrm{PCD} ;++$, genetic mutations causing $1-4 \%$ of all $\mathrm{PCD} ;+++$, genetic mutations causing $4-10 \%$ of all PCD; ++++, genetic mutations causing $>15 \%$ of all PCD; CP-RS, central pair- radial spoke; DA, dynein arm; DRC, dynein regulatory complex; IDA, inner dynein arm; IDA + MT, inner dynein arm defect with microtubule disorganization; NGS, next-generation sequencing panels commercially available; PCD, primary ciliary dyskinesia; ODA, outer dynein arm; Oligocilia, the presence of only few cilia. 
1. Armengot Carceller M, Mata Roig M, Milara Paya X, Cortijo Gimeno J: [Primary ciliary dyskinesia. Ciliopathies]. Acta otorrinolaringologica espanola 2010, 61(2):149159.

* This article reviews the PCD by fitting it into the ciliopathies. It is a more glogal view of the subject

2. Escudier E, Duquesnoy P, Papon JF, Amselem S: Ciliary defects and genetics of primary ciliary dyskinesia. Paediatric respiratory reviews 2009, 10(2):51-54.

3. Bush A, Chodhari R, Collins N, Copeland F, Hall P, Harcourt J, Hariri M, Hogg C, Lucas J, Mitchison HM et al: Primary ciliary dyskinesia: current state of the art. Archives of disease in childhood 2007, 92(12):1136-1140.

4. Daniels ML, Noone PG: Genetics, diagnosis, and future treatment strategies for primary ciliary dyskinesia. Expert opinion on orphan drugs 2015, 3(1):31-44.

5. Lucas JS, Barbato A, Collins SA, Goutaki M, Behan L, Caudri D, Dell S, Eber E, Escudier E, Hirst RA et al: European Respiratory Society guidelines for the diagnosis of primary ciliary dyskinesia. The European respiratory journal 2017, 49(1).

6. Siewart A: Über einem fall von bronchiektasis bei einem patient mit situs inversus viscerum. Klin Wschr 1904, 41:139-141.

7. Kartagener M: Zur Pathogenese der Bronchiektasien. Beitr Klin Tuberk 1933(83):489-501.

8. Afzelius BA, Eliasson R, Johnsen O, Lindholmer C: Lack of dynein arms in immotile human spermatozoa. The Journal of cell biology 1975, 66(2):225-232.

9. Afzelius BA: A human syndrome caused by immotile cilia. Science (New York, NY) 1976, 193(4250):317-319.

10. Eliasson R, Mossberg B, Camner P, Afzelius BA: The immotile-cilia syndrome. A congenital ciliary abnormality as an etiologic factor in chronic airway infections and male sterility. The New England journal of medicine 1977, 297(1):1-6.

11. Afzelius BA, Mossberg B: Immotile cilia. Thorax 1980, 35(6):401-404.

12. Afzelius BA, Camner P, Eliasson R, Mossberg B: On renaming the immotile-cilia syndrome. Lancet (London, England) 1981, 2(8251):870.

13. Rossman CM, Newhouse MT: Primary ciliary dyskinesia: evaluation and management. Pediatric pulmonology 1988, 5(1):36-50.

14. Veerman AJ, van der Baan S, Den Hollander W: [Disorders in mucociliary transport. Primary ciliary dyskinesia]. Tijdschrift voor kindergeneeskunde 1983, 51(6):185-192.

15. Mygind N, Pedersen M, Nielsen MH: Primary and secondary ciliary dyskinesia. Acta oto-laryngologica 1983, 95(5-6):688-694.

16. Behan L, Dunn Galvin A, Rubbo B, Masefield S, Copeland F, Manion M, Rindlisbacher B, Redfern B, Lucas JS: Diagnosing primary ciliary dyskinesia: an international patient perspective. The European respiratory journal 2016, 48(4):10961107.

** In this article it can be ascertained the lack of awareness of the physicians of this disease, as well as the patients themselves.

17. Kuehni CE, Frischer T, Strippoli MP, Maurer E, Bush A, Nielsen KG, Escribano A, Lucas JS, Yiallouros P, Omran $\mathrm{H}$ et al: Factors influencing age at diagnosis of primary ciliary dyskinesia in European children. The European respiratory journal 2010, 36(6):1248-1258.

18. Goutaki M, Meier AB, Halbeisen FS, Lucas JS, Dell SD, Maurer E, Casaulta C, Jurca M, Spycher BD, Kuehni CE: Clinical manifestations in primary ciliary dyskinesia: systematic review and meta-analysis. The European respiratory journal 2016, 48(4):1081-1095. 
19. Kennedy MP, Omran H, Leigh MW, Dell S, Morgan L, Molina PL, Robinson BV, Minnix SL, Olbrich H, Severin T et al: Congenital heart disease and other heterotaxic defects in a large cohort of patients with primary ciliary dyskinesia. Circulation 2007, 115(22):2814-2821.

20. Shapiro AJ, Davis SD, Ferkol T, Dell SD, Rosenfeld M, Olivier KN, Sagel SD, Milla C, Zariwala MA, Wolf W et al: Laterality defects other than situs inversus totalis in primary ciliary dyskinesia: insights into situs ambiguus and heterotaxy. Chest 2014, 146(5):1176-1186.

21. Wessels MW, den Hollander NS, Willems PJ: Mild fetal cerebral ventriculomegaly as a prenatal sonographic marker for Kartagener syndrome. Prenatal diagnosis 2003, 23(3):239-242.

22. Mullowney T, Manson D, Kim R, Stephens D, Shah V, Dell S: Primary ciliary dyskinesia and neonatal respiratory distress. Pediatrics 2014, 134(6):1160-1166.

23. Davis SD, Ferkol TW, Rosenfeld M, Lee HS, Dell SD, Sagel SD, Milla C, Zariwala MA, Pittman JE, Shapiro AJ et al: Clinical features of childhood primary ciliary dyskinesia by genotype and ultrastructural phenotype. American journal of respiratory and critical care medicine 2015, 191(3):316-324.

24. Behan L, Dimitrov BD, Kuehni CE, Hogg C, Carroll M, Evans HJ, Goutaki M, Harris A, Packham S, Walker WT et al: PICADAR: a diagnostic predictive tool for primary ciliary dyskinesia. The European respiratory journal 2016, 47(4):1103-1112.

25. Zihlif N, Paraskakis E, Lex C, Van de Pohl LA, Bush A: Correlation between cough frequency and airway inflammation in children with primary ciliary dyskinesia. Pediatric pulmonology 2005, 39(6):551-557.

26. Sommer JU, Schafer K, Omran H, Olbrich H, Wallmeier J, Blum A, Hormann K, Stuck BA: ENT manifestations in patients with primary ciliary dyskinesia: prevalence and significance of otorhinolaryngologic co-morbidities. European archives of otorhino-laryngology : official journal of the European Federation of Oto-RhinoLaryngological Societies (EUFOS) : affiliated with the German Society for OtoRhino-Laryngology - Head and Neck Surgery 2011, 268(3):383-388.

27. Majithia A, Fong J, Hariri M, Harcourt J: Hearing outcomes in children with primary ciliary dyskinesia--a longitudinal study. International journal of pediatric otorhinolaryngology 2005, 69(8):1061-1064.

28. Kennedy MP, Noone PG, Leigh MW, Zariwala MA, Minnix SL, Knowles MR, Molina PL: High-resolution CT of patients with primary ciliary dyskinesia. AJR American journal of roentgenology 2007, 188(5):1232-1238.

29. Homma S, Kawabata M, Kishi K, Tsuboi E, Narui K, Nakatani T, Saiki S, Nakata K: Bronchiolitis in Kartagener's syndrome. The European respiratory journal 1999, 14(6):1332-1339.

30. Marthin JK, Petersen N, Skovgaard LT, Nielsen KG: Lung function in patients with primary ciliary dyskinesia: a cross-sectional and 3-decade longitudinal study. American journal of respiratory and critical care medicine 2010, 181(11):1262-1268.

31. Noone PG, Leigh MW, Sannuti A, Minnix SL, Carson JL, Hazucha M, Zariwala MA, Knowles MR: Primary ciliary dyskinesia: diagnostic and phenotypic features. American journal of respiratory and critical care medicine 2004, 169(4):459-467.

32. Frija-Masson J, Bassinet L, Honore I, Dufeu N, Housset B, Coste A, Papon JF, Escudier E, Burgel PR, Maitre B: Clinical characteristics, functional respiratory decline and follow-up in adult patients with primary ciliary dyskinesia. Thorax 2016.

33. Sha YW, Ding L, Li P: Management of primary ciliary dyskinesia/Kartagener's syndrome in infertile male patients and current progress in defining the underlying genetic mechanism. Asian journal of andrology 2014, 16(1):101-106. 
34. Munro NC, Currie DC, Lindsay KS, Ryder TA, Rutman A, Dewar A, Greenstone MA, Hendry WF, Cole PJ: Fertility in men with primary ciliary dyskinesia presenting with respiratory infection. Thorax 1994, 49(7):684-687.

35. Halbert SA, Patton DL, Zarutskie PW, Soules MR: Function and structure of cilia in the fallopian tube of an infertile woman with Kartagener's syndrome. Human reproduction (Oxford, England) 1997, 12(1):55-58.

36. Lucas JS, Barbato A, Collins SA, Goutaki M, Behan L, Caudri D, Dell S, Eber E, Escudier E, Hirst RA et al: European Respiratory Society guidelines for the diagnosis of primary ciliary dyskinesia. The European respiratory journal 2016.

**This article provides the gidelines for PCD diagnosis considering all diagnostic tools available.

37. Leigh MW, Ferkol TW, Davis SD, Lee HS, Rosenfeld M, Dell SD, Sagel SD, Milla C, Olivier KN, Sullivan KM et al: Clinical Features and Associated Likelihood of Primary Ciliary Dyskinesia in Children and Adolescents. Annals of the American Thoracic Society 2016.

38. Shapiro AJ, Zariwala MA, Ferkol T, Davis SD, Sagel SD, Dell SD, Rosenfeld M, Olivier KN, Milla C, Daniel SJ et al: Diagnosis, monitoring, and treatment of primary ciliary dyskinesia: PCD foundation consensus recommendations based on state of the art review. Pediatric pulmonology 2016, 51(2):115-132.

39. Armengot M, Milara J, Mata M, Carda C, Cortijo J: Cilia motility and structure in primary and secondary ciliary dyskinesia. American journal of rhinology \& allergy 2010, 24(3):175-180.

40. Collins SA, Gove K, Walker W, Lucas JS: Nasal nitric oxide screening for primary ciliary dyskinesia: systematic review and meta-analysis. The European respiratory journal 2014, 44(6):1589-1599.

41. Jackson CL, Behan L, Collins SA, Goggin PM, Adam EC, Coles JL, Evans HJ, Harris A, Lackie P, Packham S et al: Accuracy of diagnostic testing in primary ciliary dyskinesia. The European respiratory journal 2016, 47(3):837-848.

42. Hirst RA, Jackson CL, Coles JL, Williams G, Rutman A, Goggin PM, Adam EC, Page A, Evans HJ, Lackie PM et al: Culture of primary ciliary dyskinesia epithelial cells at air-liquid interface can alter ciliary phenotype but remains a robust and informative diagnostic aid. PloS one 2014, 9(2):e89675.

43. Papon JF, Coste A, Roudot-Thoraval F, Boucherat M, Roger G, Tamalet A, Vojtek AM, Amselem S, Escudier E: A 20-year experience of electron microscopy in the diagnosis of primary ciliary dyskinesia. The European respiratory journal 2010, 35(5):1057-1063.

44. Shoemark A, Dixon M, Corrin B, Dewar A: Twenty-year review of quantitative transmission electron microscopy for the diagnosis of primary ciliary dyskinesia. Journal of clinical pathology 2012, 65(3):267-271.

45. Lucas JS, Paff T, Goggin P, Haarman E: Diagnostic Methods in Primary Ciliary Dyskinesia. Paediatric respiratory reviews 2016, 18:8-17.

46. Abitbul R, Amirav I, Blau H, Alkrinawi S, Aviram M, Shoseyov D, Bentur L, Avital A, Springer C, Lavie M et al: Primary ciliary dyskinesia in Israel: Prevalence, clinical features, current diagnosis and management practices. Respiratory medicine 2016, 119:41-47.

47. Barbato A, Frischer T, Kuehni CE, Snijders D, Azevedo I, Baktai G, Bartoloni L, Eber E, Escribano A, Haarman E et al: Primary ciliary dyskinesia: a consensus statement on diagnostic and treatment approaches in children. The European respiratory journal 2009, 34(6):1264-1276. 
48. Polineni D, Davis SD, Dell SD: Treatment recommendations in Primary Ciliary Dyskinesia. Paediatric respiratory reviews 2016, 18:39-45.

49. Kobbernagel HE, Buchvald FF, Haarman EG, Casaulta C, Collins SA, Hogg C, Kuehni CE, Lucas JS, Omran H, Quittner AL et al: Study protocol, rationale and recruitment in a European multi-centre randomized controlled trial to determine the efficacy and safety of azithromycin maintenance therapy for 6 months in primary ciliary dyskinesia. BMC pulmonary medicine 2016, 16(1):104.

50. Bhatt JM: Treatment of pulmonary exacerbations in cystic fibrosis. European respiratory review : an official journal of the European Respiratory Society 2013, 22(129):205-216.

51. Stafanger G, Garne S, Howitz P, Morkassel E, Koch C: The clinical effect and the effect on the ciliary motility of oral $\mathrm{N}$-acetylcysteine in patients with cystic fibrosis and primary ciliary dyskinesia. The European respiratory journal 1988, 1(2):161-167.

52. Chang CC, Morris PS, Chang AB: Influenza vaccine for children and adults with bronchiectasis. The Cochrane database of systematic reviews 2007(3):Cd006218.

53. Nuorti JP, Whitney CG: Prevention of pneumococcal disease among infants and children - use of 13-valent pneumococcal conjugate vaccine and 23-valent pneumococcal polysaccharide vaccine - recommendations of the Advisory Committee on Immunization Practices (ACIP). MMWR Recommendations and reports : Morbidity and mortality weekly report Recommendations and reports 2010, 59(Rr11):1-18.

54. Campbell R: Managing upper respiratory tract complications of primary ciliary dyskinesia in children. Current opinion in allergy and clinical immunology 2012, 12(1):32-38.

55. Pruliere-Escabasse V, Coste A, Chauvin P, Fauroux B, Tamalet A, Garabedian EN, Escudier E, Roger G: Otologic features in children with primary ciliary dyskinesia. Archives of otolaryngology--head \& neck surgery 2010, 136(11):1121-1126.

56. Deuse T, Reitz BA: Heart-lung transplantation in situs inversus totalis. The Annals of thoracic surgery 2009, 88(3):1002-1003.

57. Otgun I, Karnak I, Tanyel FC, Senocak ME, Buyukpamukcu N: Surgical treatment of bronchiectasis in children. Journal of pediatric surgery 2004, 39(10):1532-1536.

58. Tkebuchava T, Niederhauser U, Weder W, von Segesser LK, Bauersfeld U, Felix H, Lachat M, Turina MI: Kartagener's syndrome: clinical presentation and cardiosurgical aspects. The Annals of thoracic surgery 1996, 62(5):1474-1479.

59. Lin TK, Lee RK, Su JT, Liu WY, Lin MH, Hwu YM: A successful pregnancy with in vitro fertilization and embryo transfer in an infertile woman with Kartagener's syndrome: a case report. Journal of assisted reproduction and genetics 1998, 15(10):625-627.

60. Corkey CW, Levison H, Turner JA: The immotile cilia syndrome. A longitudinal survey. The American review of respiratory disease 1981, 124(5):544-548.

61. Hellinckx J, Demedts M, De Boeck K: Primary ciliary dyskinesia: evolution of pulmonary function. European journal of pediatrics 1998, 157(5):422-426.

62. Ellerman A, Bisgaard H: Longitudinal study of lung function in a cohort of primary ciliary dyskinesia. The European respiratory journal 1997, 10(10):2376-2379.

63. Maglione M, Bush A, Montella S, Mollica C, Manna A, Esposito A, Santamaria F: Progression of lung disease in primary ciliary dyskinesia: is spirometry less accurate than CT? Pediatric pulmonology 2012, 47(5):498-504.

64. Magnin ML, Cros P, Beydon N, Mahloul M, Tamalet A, Escudier E, Clement A, Le Pointe HD, Blanchon S: Longitudinal lung function and structural changes in children with primary ciliary dyskinesia. Pediatric pulmonology 2012, 47(8):816-825. 
65. Shah A, Shoemark A, MacNeill SJ, Bhaludin B, Rogers A, Bilton D, Hansell DM, Wilson R, Loebinger MR: A longitudinal study characterising a large adult primary ciliary dyskinesia population. The European respiratory journal 2016, 48(2):441-450.

66. Mata M, Lluch-Estelles J, Armengot M, Sarrion I, Carda C, Cortijo J: New adenylate kinase 7 (AK7) mutation in primary ciliary dyskinesia. American journal of rhinology \& allergy 2012, 26(4):260-264.

67. Lai M, Pifferi M, Bush A, Piras M, Michelucci A, Di Cicco M, del Grosso A, Quaranta P, Cursi C, Tantillo E et al: Gene editing of DNAH1 1 restores normal cilia motility in primary ciliary dyskinesia. Journal of medical genetics 2016, 53(4):242249.

*This study demonstrates that gene editing can rescue ciliary beating ex vivo, opening up new avenues for treating $P C D$.

68. Pennarun G, Escudier E, Chapelin C, Bridoux AM, Cacheux V, Roger G, Clement A, Goossens M, Amselem S, Duriez B: Loss-of-function mutations in a human gene related to Chlamydomonas reinhardtii dynein IC78 result in primary ciliary dyskinesia. AmJHumGenet 1999, 65(6):1508-1519.

69. O'Toole ET, Giddings TH, Jr., Porter ME, Ostrowski LE: Computer-assisted image analysis of human cilia and Chlamydomonas flagella reveals both similarities and differences in axoneme structure. Cytoskeleton (Hoboken, NJ) 2012, 69(8):577-590.

70. Wirschell M, Olbrich H, Werner C, Tritschler D, Bower R, Sale WS, Loges NT, Pennekamp P, Lindberg S, Stenram U et al: The nexin-dynein regulatory complex subunit DRC1 is essential for motile cilia function in algae and humans. Nature genetics 2013, 45(3):262-268.

71. Horani A, Brody SL, Ferkol TW, Shoseyov D, Wasserman MG, Ta-shma A, Wilson KS, Bayly PV, Amirav I, Cohen-Cymberknoh M et al: CCDC65 mutation causes primary ciliary dyskinesia with normal ultrastructure and hyperkinetic cilia. PloS one 2013, 8(8):e72299.

72. Boon M, Wallmeier J, Ma L, Loges NT, Jaspers M, Olbrich H, Dougherty GW, Raidt $\mathrm{J}$, Werner C, Amirav I et al: MCIDAS mutations result in a mucociliary clearance disorder with reduced generation of multiple motile cilia. Nature communications 2014, 5:4418.

73. Zariwala MA, Gee HY, Kurkowiak M, Al-Mutairi DA, Leigh MW, Hurd TW, Hjeij R, Dell SD, Chaki M, Dougherty GW et al: ZMYND10 is mutated in primary ciliary dyskinesia and interacts with LRRC6. American journal of human genetics 2013, 93(2):336-345.

74. Austin-Tse C, Halbritter J, Zariwala MA, Gilberti RM, Gee HY, Hellman N, Pathak N, Liu Y, Panizzi JR, Patel-King RS et al: Zebrafish Ciliopathy Screen Plus Human Mutational Analysis Identifies C21orf59 and CCDC65 Defects as Causing Primary Ciliary Dyskinesia. American journal of human genetics 2013, 93(4):672-686.

75. Li Y, Yagi H, Onuoha EO, Damerla RR, Francis R, Furutani Y, Tariq M, King SM, Hendricks G, Cui C et al: DNAH6 and Its Interactions with PCD Genes in Heterotaxy and Primary Ciliary Dyskinesia. PLoS genetics 2016, 12(2):e1005821.

76. Tarkar A, Loges NT, Slagle CE, Francis R, Dougherty GW, Tamayo JV, Shook B, Cantino M, Schwartz D, Jahnke C et al: DYX1C1 is required for axonemal dynein assembly and ciliary motility. Nature genetics 2013, 45(9):995-1003.

77. Norris DP, Grimes DT: Mouse models of ciliopathies: the state of the art. Disease models \& mechanisms 2012, 5(3):299-312.

78. Ibanez-Tallon I, Gorokhova S, Heintz N: Loss of function of axonemal dynein Mdnah5 causes primary ciliary dyskinesia and hydrocephalus. Human molecular genetics 2002, 11(6):715-721. 
79. Lee L: Riding the wave of ependymal cilia: genetic susceptibility to hydrocephalus in primary ciliary dyskinesia. Journal of neuroscience research 2013, 91(9):1117-1132.

80. Lucas JS, Adam EC, Goggin PM, Jackson CL, Powles-Glover N, Patel SH, Humphreys J, Fray MD, Falconnet E, Blouin JL et al: Static respiratory cilia associated with mutations in Dnahc11/DNAH11: a mouse model of PCD. Human mutation 2012, 33(3):495-503.

81. Vincensini L, Blisnick T, Bastin P: 1001 model organisms to study cilia and flagella. Biology of the cell 2011, 103(3):109-130.

82. Ostrowski LE, Dutcher SK, Lo CW: Cilia and models for studying structure and function. Proceedings of the American Thoracic Society 2011, 8(5):423-429.

83. Lee L: Mechanisms of mammalian ciliary motility: Insights from primary ciliary dyskinesia genetics. Gene 2011, 473(2):57-66.

84. Marthin JK, Petersen N, Skovgaard LT, Nielsen KG: Lung function in patients with primary ciliary dyskinesia: a cross-sectional and 3-decade longitudinal study. AmJRespirCrit Care Med 2010, 181(11):1262-1268.

85. Maglione M, Bush A, Nielsen KG, Hogg C, Montella S, Marthin JK, Di Giorgio A, Santamaria F: Multicenter analysis of body mass index, lung function, and sputum microbiology in primary ciliary dyskinesia. Pediatric pulmonology 2014, 49(12):1243-1250.

86. Lucas JS, Leigh MW: Diagnosis of primary ciliary dyskinesia: searching for a gold standard. The European respiratory journal 2014, 44(6):1418-1422.

87. Strippoli MP, Frischer T, Barbato A, Snijders D, Maurer E, Lucas JS, Eber E, Karadag B, Pohunek P, Zivkovic Z et al: Management of primary ciliary dyskinesia in European children: recommendations and clinical practice. EurRespirJ 2012, 39(6):1482-1491.

88. Papon JF, Bassinet L, Cariou-Patron G, Zerah-Lancner F, Vojtek AM, Blanchon S, Crestani B, Amselem S, Coste A, Housset B et al: Quantitative analysis of ciliary beating in primary ciliary dyskinesia: a pilot study. Orphanet journal of rare diseases 2012, 7:78.

89. Papon JF, Coste A, Roudot-Thoraval F, Boucherat M, Roger G, Tamalet A, Vojtek AM, Amselem S, Escudier E: A 20-year experience of electron microscopy in the diagnosis of primary ciliary dyskinesia. EurRespirJ 2010, 35(5):1057-1063.

90. Stannard WA, Chilvers MA, Rutman AR, Williams CD, O'Callaghan C: Diagnostic testing of patients suspected of primary ciliary dyskinesia. American journal of respiratory and critical care medicine 2010, 181(4):307-314.

91. Olin JT, Burns K, Carson JL, Metjian H, Atkinson JJ, Davis SD, Dell SD, Ferkol TW, Milla CE, Olivier KN et al: Diagnostic yield of nasal scrape biopsies in primary ciliary dyskinesia: a multicenter experience. Pediatric pulmonology 2011, 46(5):483488.

92. Shoemark A, Dixon M, Corrin B, Dewar A: Twenty-year review of quantitative transmission electron microscopy for the diagnosis of primary ciliary dyskinesia. JClinPathol 2012, 65(3):267-271.

93. Boon M, Smits A, Cuppens H, Jaspers M, Proesmans M, Dupont LJ, Vermeulen FL, Van Daele S, Malfroot A, Godding V et al: Primary ciliary dyskinesia: critical evaluation of clinical symptoms and diagnosis in patients with normal and abnormal ultrastructure. Orphanet journal of rare diseases 2014, 9:11.

94. Jorissen M, Willems T, Van der Schueren B, Verbeken E, De BK: Ultrastructural expression of primary ciliary dyskinesia after ciliogenesis in culture. Acta OtorhinolaryngolBelg 2000, 54(3):343-356. 
95. Kim RH, D AH, Cutz E, Knowles MR, Nelligan KA, Nykamp K, Zariwala MA, Dell SD: The role of molecular genetic analysis in the diagnosis of primary ciliary dyskinesia. Annals of the American Thoracic Society 2014, 11(3):351-359.

96. Burgoyne T, Dixon M, Luther P, Hogg C, Shoemark A: Generation of a threedimensional ultrastructural model of human respiratory cilia. American journal of respiratory cell and molecular biology 2012, 47(6):800-806.

97. Burgoyne T, Lewis A, Dewar A, Luther P, Hogg C, Shoemark A, Dixon M: Characterizing the ultrastructure of primary ciliary dyskinesia transposition defect using electron tomography. Cytoskeleton (Hoboken, NJ) 2014, 71(5):294-301.

98. Marthin JK, Mortensen J, Pressler T, Nielsen KG: Pulmonary radioaerosol mucociliary clearance in diagnosis of primary ciliary dyskinesia. Chest 2007, 132(3):966-976.

99. Walker WT, Young A, Bennett M, Guy M, Carroll M, Fleming J, Conway J, Lucas JS: Pulmonary radioaerosol mucociliary clearance in primary ciliary dyskinesia. The European respiratory journal 2014, 44(2):533-535.

100. Shoemark A, Hogg C: Electron tomography of respiratory cilia. Thorax 2013, 68(2):190-191.

101. Olbrich H, Schmidts M, Werner C, Onoufriadis A, Loges NT, Raidt J, Banki NF, Shoemark A, Burgoyne T, Al Turki S et al: Recessive HYDIN mutations cause primary ciliary dyskinesia without randomization of left-right body asymmetry. American journal of human genetics 2012, 91(4):672-684.

102. Ellerman A, Bisgaard H: Longitudinal study of lung function in a cohort of primary ciliary dyskinesia. EurRespirJ 1997, 10(10):2376-2379.

103. Magnin ML, Cros P, Beydon N, Mahloul M, Tamalet A, Escudier E, Clement A, Le Pointe HD, Blanchon S: Longitudinal lung function and structural changes in children with primary ciliary dyskinesia. PediatrPulmonol 2012, 47(8):816-825.

104. Green K, Buchvald FF, Marthin JK, Hanel B, Gustafsson PM, Nielsen KG: Ventilation inhomogeneity in children with primary ciliary dyskinesia. Thorax 2012, 67(1):49-53.

105. Irving SJ, Ives A, Davies G, Donovan J, Edey AJ, Gill SS, Nair A, Saunders C, Wijesekera NT, Alton EW et al: Lung clearance index and high-resolution computed tomography scores in primary ciliary dyskinesia. AmJRespirCrit Care Med 2013, 188(5):545-549.

106. Boon M, Vermeulen FL, Gysemans W, Proesmans M, Jorissen M, De Boeck K: Lung structure-function correlation in patients with primary ciliary dyskinesia. Thorax 2015, 70(4):339-345.

107. Nyilas S, Schlegtendal A, Yammine S, Casaulta C, Latzin P, Koerner-Rettberg C: Further evidence for an association between LCI and FEV1 in patients with PCD. Thorax 2015, 70(9):896.

108. Bush A, Irving S: Wavering in the breeze: is multiple breath washout useful in primary ciliary dyskinesia? Thorax 2015, 70(4):305-306.

109. Lucas JS, Behan L, Dunn Galvin A, Alpern A, Morris AM, Carroll MP, Knowles MR, Leigh MW, Quittner AL: A quality-of-life measure for adults with primary ciliary dyskinesia: QOL-PCD. The European respiratory journal 2015.

110. Dell SD, Leigh MW, Lucas JS, Ferkol TW, Knowles MR, Alpern A, Behan L, Morris AM, Hogg C, DunnGalvin A et al: Primary Ciliary Dyskinesia: First Health-related Quality-of-Life Measures for Pediatric Patients. Annals of the American Thoracic Society 2016, 13(10):1726-1735. 
111. Behan LL, MW; Dell, SD; Galvin, AD; Quittner, AL; Lucas, JS.: Validation of a health-related quality of life instrument for primary ciliary dyskinesia: QOL-PCD. Thorax in press 2017.

112. Leigh MW, Hazucha MJ, Chawla KK, Baker BR, Shapiro AJ, Brown DE, Lavange LM, Horton BJ, Qaqish B, Carson JL et al: Standardizing nasal nitric oxide measurement as a test for primary ciliary dyskinesia. AnnAmThoracSoc 2013, 10(6):574-581.

113. Shapiro AJ, Davis SD, Ferkol T, Dell SD, Rosenfeld M, Olivier KN, Sagel SD, Milla C, Zariwala MA, Wolf W et al: Laterality Defects other than Situs Inversus Totalis in Primary Ciliary Dyskinesia: Insights into Situs Ambiguus and Heterotaxy. Chest 2014.

114. Knowles MR, Daniels LA, Davis SD, Zariwala MA, Leigh MW: Primary ciliary dyskinesia. Recent advances in diagnostics, genetics, and characterization of clinical disease. American journal of respiratory and critical care medicine 2013, 188(8):913922.

115. Barbato A, Frischer T, Kuehni CE, Snijders D, Azevedo I, Baktai G, Bartoloni L, Eber E, Escribano A, Haarman E et al: Primary ciliary dyskinesia: a consensus statement on diagnostic and treatment approaches in children. EurRespirJ 2009, 34(6):1264-1276.

116. Kuehni CE, Frischer T, Strippoli MP, Maurer E, Bush A, Nielsen KG, Escribano A, Lucas JS, Yiallouros $\mathrm{P}$, Omran $\mathrm{H}$ et al: Factors influencing age at diagnosis of primary ciliary dyskinesia in European children. EurRespirJ 2010, 36(6):1248-1258.

117. Werner C, Lablans M, Ataian M, Raidt J, Wallmeier J, Grosse-Onnebrink J, Kuehni CE, Haarman EG, Leigh MW, Quittner AL et al: An international registry for primary ciliary dyskinesia. The European respiratory journal 2016, 47(3):849-859.

118. Hornef N, Olbrich H, Horvath J, Zariwala MA, Fliegauf M, Loges NT, Wildhaber J, Noone PG, Kennedy M, Antonarakis SE et al: DNAH5 mutations are a common cause of primary ciliary dyskinesia with outer dynein arm defects. American journal of respiratory and critical care medicine 2006, 174(2):120-126.

119. Olbrich H, Haffner K, Kispert A, Volkel A, Volz A, Sasmaz G, Reinhardt R, Hennig $\mathrm{S}$, Lehrach H, Konietzko N et al: Mutations in DNAH5 cause primary ciliary dyskinesia and randomization of left-right asymmetry. Nature genetics 2002, 30(2):143-144.

120. Omran H, Haffner K, Volkel A, Kuehr J, Ketelsen UP, Ross UH, Konietzko N, Wienker T, Brandis M, Hildebrandt F: Homozygosity mapping of a gene locus for primary ciliary dyskinesia on chromosome $5 \mathrm{p}$ and identification of the heavy dynein chain DNAH5 as a candidate gene. American journal of respiratory cell and molecular biology 2000, 23(5):696-702.

121. Failly M, Saitta A, Munoz A, Falconnet E, Rossier C, Santamaria F, de Santi MM, Lazor R, DeLozier-Blanchet CD, Bartoloni L et al: DNAI1 mutations explain only $2 \%$ of primary ciliary dykinesia. Respiration; international review of thoracic diseases 2008, 76(2):198-204.

122. Horvath J, Fliegauf M, Olbrich H, Kispert A, King SM, Mitchison H, Zariwala MA, Knowles MR, Sudbrak R, Fekete $\mathrm{G}$ et al: Identification and analysis of axonemal dynein light chain 1 in primary ciliary dyskinesia patients. American journal of respiratory cell and molecular biology 2005, 33(1):41-47.

123. Pennarun G, Escudier E, Chapelin C, Bridoux AM, Cacheux V, Roger G, Clement A, Goossens M, Amselem S, Duriez B: Loss-of-function mutations in a human gene related to Chlamydomonas reinhardtii dynein IC78 result in primary ciliary dyskinesia. American journal of human genetics 1999, 65(6):1508-1519. 
124. Zariwala MA, Leigh MW, Ceppa F, Kennedy MP, Noone PG, Carson JL, Hazucha MJ, Lori A, Horvath J, Olbrich H et al: Mutations of DNAI1 in primary ciliary dyskinesia: evidence of founder effect in a common mutation. American journal of respiratory and critical care medicine 2006, 174(8):858-866.

125. Zietkiewicz E, Nitka B, Voelkel K, Skrzypczak U, Bukowy Z, Rutkiewicz E, Huminska K, Przystalowska H, Pogorzelski A, Witt M: Population specificity of the DNAI1 gene mutation spectrum in primary ciliary dyskinesia (PCD). Respiratory research 2010, 11:174.

126. Loges NT, Olbrich H, Fenske L, Mussaffi H, Horvath J, Fliegauf M, Kuhl H, Baktai G, Peterffy E, Chodhari R et al: DNAI2 mutations cause primary ciliary dyskinesia with defects in the outer dynein arm. American journal of human genetics 2008, 83(5):547-558.

127. Mazor M, Alkrinawi S, Chalifa-Caspi V, Manor E, Sheffield VC, Aviram M, Parvari R: Primary ciliary dyskinesia caused by homozygous mutation in DNAL1, encoding dynein light chain 1. American journal of human genetics 2011, 88(5):599-607.

128. Knowles MR, Leigh MW, Ostrowski LE, Huang L, Carson JL, Hazucha MJ, Yin W, Berg JS, Davis SD, Dell SD et al: Exome sequencing identifies mutations in CCDC114 as a cause of primary ciliary dyskinesia. American journal of human genetics 2013, 92(1):99-106.

129. Onoufriadis A, Paff T, Antony D, Shoemark A, Micha D, Kuyt B, Schmidts M, Petridi S, Dankert-Roelse JE, Haarman EG et al: Splice-site mutations in the axonemal outer dynein arm docking complex gene CCDC114 cause primary ciliary dyskinesia. American journal of human genetics 2013, 92(1):88-98.

130. Wallmeier J, Shiratori H, Dougherty GW, Edelbusch C, Hjeij R, Loges NT, Menchen T, Olbrich H, Pennekamp P, Raidt J et al: TTC25 Deficiency Results in Defects of the Outer Dynein Arm Docking Machinery and Primary Ciliary Dyskinesia with LeftRight Body Asymmetry Randomization. American journal of human genetics 2016, 99(2):460-469.

131. Alsaadi MM, Erzurumluoglu AM, Rodriguez S, Guthrie PA, Gaunt TR, Omar HZ, Mubarak M, Alharbi KK, Al-Rikabi AC, Day IN: Nonsense mutation in coiled-coil domain containing 151 gene (CCDC151) causes primary ciliary dyskinesia. Human mutation 2014, 35(12):1446-1448.

132. Hjeij R, Onoufriadis A, Watson CM, Slagle CE, Klena NT, Dougherty GW, Kurkowiak M, Loges NT, Diggle CP, Morante NF et al: CCDC151 mutations cause primary ciliary dyskinesia by disruption of the outer dynein arm docking complex formation. American journal of human genetics 2014, 95(3):257-274.

133. Hjeij R, Lindstrand A, Francis R, Zariwala MA, Liu X, Li Y, Damerla R, Dougherty GW, Abouhamed M, Olbrich $\mathrm{H}$ et al: ARMC4 mutations cause primary ciliary dyskinesia with randomization of left/right body asymmetry. American journal of human genetics 2013, 93(2):357-367.

134. Onoufriadis A, Shoemark A, Munye MM, James CT, Schmidts M, Patel M, Rosser EM, Bacchelli C, Beales PL, Scambler PJ et al: Combined exome and whole-genome sequencing identifies mutations in ARMC4 as a cause of primary ciliary dyskinesia with defects in the outer dynein arm. Journal of medical genetics 2014, 51(1):61-67.

135. Panizzi JR, Becker-Heck A, Castleman VH, Al-Mutairi DA, Liu Y, Loges NT, Pathak N, Austin-Tse C, Sheridan E, Schmidts M et al: CCDC103 mutations cause primary ciliary dyskinesia by disrupting assembly of ciliary dynein arms. Nature genetics 2012, 44(6):714-719.

136. Duriez B, Duquesnoy P, Escudier E, Bridoux AM, Escalier D, Rayet I, Marcos E, Vojtek AM, Bercher JF, Amselem S: A common variant in combination with a 
nonsense mutation in a member of the thioredoxin family causes primary ciliary dyskinesia. Proceedings of the National Academy of Sciences of the United States of America 2007, 104(9):3336-3341.

137. Duquesnoy P, Escudier E, Vincensini L, Freshour J, Bridoux AM, Coste A, Deschildre A, de Blic J, Legendre M, Montantin G et al: Loss-of-function mutations in the human ortholog of Chlamydomonas reinhardtii ODA7 disrupt dynein arm assembly and cause primary ciliary dyskinesia. American journal of human genetics 2009, 85(6):890-896.

138. Loges NT, Olbrich H, Becker-Heck A, Haffner K, Heer A, Reinhard C, Schmidts M, Kispert A, Zariwala MA, Leigh MW et al: Deletions and point mutations of LRRC50 cause primary ciliary dyskinesia due to dynein arm defects. American journal of human genetics 2009, 85(6):883-889.

139. Omran H, Kobayashi D, Olbrich H, Tsukahara T, Loges NT, Hagiwara H, Zhang Q, Leblond G, O'Toole E, Hara C et al: Ktu/PF13 is required for cytoplasmic preassembly of axonemal dyneins. Nature 2008, 456(7222):611-616.

140. Mitchison HM, Schmidts M, Loges NT, Freshour J, Dritsoula A, Hirst RA, O'Callaghan C, Blau H, Al Dabbagh M, Olbrich H et al: Mutations in axonemal dynein assembly factor DNAAF3 cause primary ciliary dyskinesia. Nature genetics 2012, 44(4):381-389, s381-382.

141. Horani A, Ferkol TW, Shoseyov D, Wasserman MG, Oren YS, Kerem B, Amirav I, Cohen-Cymberknoh M, Dutcher SK, Brody SL et al: LRRC6 mutation causes primary ciliary dyskinesia with dynein arm defects. PloS one 2013, 8(3):e59436.

142. Kott E, Duquesnoy P, Copin B, Legendre M, Dastot-Le Moal F, Montantin G, Jeanson L, Tamalet A, Papon JF, Siffroi JP et al: Loss-of-function mutations in LRRC6, a gene essential for proper axonemal assembly of inner and outer dynein arms, cause primary ciliary dyskinesia. American journal of human genetics 2012, 91(5):958-964.

143. Horani A, Druley TE, Zariwala MA, Patel AC, Levinson BT, Van Arendonk LG, Thornton KC, Giacalone JC, Albee AJ, Wilson KS et al: Whole-exome capture and sequencing identifies HEATR2 mutation as a cause of primary ciliary dyskinesia. American journal of human genetics 2012, 91(4):685-693.

144. Tarkar A, Loges NT, Slagle CE, Francis R, Dougherty GW, Tamayo JV, Shook B, Cantino M, Schwartz D, Jahnke C et al: DYX1C1 is required for axonemal dynein assembly and ciliary motility. Nature genetics 2013, 45(9):995-1003.

145. Moore DJ, Onoufriadis A, Shoemark A, Simpson MA, zur Lage PI, de Castro SC, Bartoloni L, Gallone G, Petridi S, Woollard WJ et al: Mutations in ZMYND10, a gene essential for proper axonemal assembly of inner and outer dynein arms in humans and flies, cause primary ciliary dyskinesia. American journal of human genetics 2013, 93(2):346-356.

146. Knowles MR, Ostrowski LE, Loges NT, Hurd T, Leigh MW, Huang L, Wolf WE, Carson JL, Hazucha MJ, Yin W et al: Mutations in SPAG1 cause primary ciliary dyskinesia associated with defective outer and inner dynein arms. American journal of human genetics 2013, 93(4):711-720.

147. Imtiaz F, Allam R, Ramzan K, Al-Sayed M: Variation in DNAH1 may contribute to primary ciliary dyskinesia. BMC medical genetics 2015, 16:14.

148. Bukowy-Bieryllo Z, Zietkiewicz E, Loges NT, Wittmer M, Geremek M, Olbrich H, Fliegauf M, Voelkel K, Rutkiewicz E, Rutland J et al: RPGR mutations might cause reduced orientation of respiratory cilia. Pediatric pulmonology 2013, 48(4):352-363.

149. Moore A, Escudier E, Roger G, Tamalet A, Pelosse B, Marlin S, Clement A, Geremek M, Delaisi B, Bridoux AM et al: RPGR is mutated in patients with a 
complex X linked phenotype combining primary ciliary dyskinesia and retinitis pigmentosa. Journal of medical genetics 2006, 43(4):326-333.

150. Budny B, Chen W, Omran H, Fliegauf M, Tzschach A, Wisniewska M, Jensen LR, Raynaud M, Shoichet SA, Badura M et al: A novel X-linked recessive mental retardation syndrome comprising macrocephaly and ciliary dysfunction is allelic to oral-facial-digital type I syndrome. Human genetics 2006, 120(2):171-178.

151. Paff T, Loges NT, Aprea I, Wu K, Bakey Z, Haarman EG, Daniels JM, Sistermans EA, Bogunovic N, Dougherty GW et al: Mutations in PIH1D3 Cause X-Linked Primary Ciliary Dyskinesia with Outer and Inner Dynein Arm Defects. American journal of human genetics 2017, 100(1):160-168.

152. Knowles MR, Leigh MW, Carson JL, Davis SD, Dell SD, Ferkol TW, Olivier KN, Sagel SD, Rosenfeld M, Burns KA et al: Mutations of DNAH11 in patients with primary ciliary dyskinesia with normal ciliary ultrastructure. Thorax 2012, 67(5):433441.

153. Pifferi M, Michelucci A, Conidi ME, Cangiotti AM, Simi P, Macchia P, Boner AL: New DNAH1 1 mutations in primary ciliary dyskinesia with normal axonemal ultrastructure. The European respiratory journal 2010, 35(6):1413-1416.

154. Olbrich H, Schmidts M, Werner C, Onoufriadis A, Loges NT, Raidt J, Banki NF, Shoemark A, Burgoyne T, Al Turki S et al: Recessive HYDIN mutations cause primary ciliary dyskinesia without randomization of left-right body asymmetry. American journal of human genetics 2012, 91(4):672-684.

155. Jeanson L, Thomas L, Copin B, Coste A, Sermet-Gaudelus I, Moal FD, Duquesnoy P, Montantin G, Collot N, Tissier S et al: Mutations in GAS8, A Gene Encoding A Nexin-Dynein Regulatory Complex Subunit, Cause Primary Ciliary Dyskinesia With Axonemal Disorganization. Human mutation 2016.

156. Blanchon S, Legendre M, Copin B, Duquesnoy P, Montantin G, Kott E, Dastot F, Jeanson L, Cachanado M, Rousseau A et al: Delineation of CCDC39/CCDC40 mutation spectrum and associated phenotypes in primary ciliary dyskinesia. Journal of medical genetics 2012, 49(6):410-416.

157. Merveille AC, Davis EE, Becker-Heck A, Legendre M, Amirav I, Bataille G, Belmont J, Beydon N, Billen F, Clement A et al: CCDC39 is required for assembly of inner dynein arms and the dynein regulatory complex and for normal ciliary motility in humans and dogs. Nature genetics 2011, 43(1):72-78.

158. Becker-Heck A, Zohn IE, Okabe N, Pollock A, Lenhart KB, Sullivan-Brown J, McSheene J, Loges NT, Olbrich H, Haeffner K et al: The coiled-coil domain containing protein CCDC40 is essential for motile cilia function and left-right axis formation. Nature genetics 2011, 43(1):79-84.

159. Castleman VH, Romio L, Chodhari R, Hirst RA, de Castro SC, Parker KA, YbotGonzalez P, Emes RD, Wilson SW, Wallis C et al: Mutations in radial spoke head protein genes RSPH9 and RSPH4A cause primary ciliary dyskinesia with centralmicrotubular-pair abnormalities. American journal of human genetics 2009, 84(2):197-209.

160. Kott E, Legendre M, Copin B, Papon JF, Dastot-Le Moal F, Montantin G, Duquesnoy P, Piterboth W, Amram D, Bassinet L et al: Loss-of-function mutations in RSPH1 cause primary ciliary dyskinesia with central-complex and radial-spoke defects. American journal of human genetics 2013, 93(3):561-570.

161. Zietkiewicz E, Bukowy-Bieryllo Z, Voelkel K, Klimek B, Dmenska H, Pogorzelski A, Sulikowska-Rowinska A, Rutkiewicz E, Witt M: Mutations in radial spoke head genes and ultrastructural cilia defects in East-European cohort of primary ciliary dyskinesia patients. PloS one 2012, 7(3):e33667. 
162. Knowles MR, Ostrowski LE, Leigh MW, Sears PR, Davis SD, Wolf WE, Hazucha MJ, Carson JL, Olivier KN, Sagel SD et al: Mutations in RSPH1 cause primary ciliary dyskinesia with a unique clinical and ciliary phenotype. American journal of respiratory and critical care medicine 2014, 189(6):707-717.

163. Onoufriadis A, Shoemark A, Schmidts M, Patel M, Jimenez G, Liu H, Thomas B, Dixon M, Hirst RA, Rutman A et al: Targeted NGS gene panel identifies mutations in RSPH1 causing primary ciliary dyskinesia and a common mechanism for ciliary central pair agenesis due to radial spoke defects. Human molecular genetics 2014, 23(13):3362-3374.

164. Jeanson L, Copin B, Papon JF, Dastot-Le Moal F, Duquesnoy P, Montantin G, Cadranel J, Corvol H, Coste A, Desir J et al: RSPH3 Mutations Cause Primary Ciliary Dyskinesia with Central-Complex Defects and a Near Absence of Radial Spokes. American journal of human genetics 2015, 97(1):153-162.

165. El Khouri E, Thomas L, Jeanson L, Bequignon E, Vallette B, Duquesnoy P, Montantin G, Copin B, Dastot-Le Moal F, Blanchon S et al: Mutations in DNAJB13, Encoding an HSP40 Family Member, Cause Primary Ciliary Dyskinesia and Male Infertility. American journal of human genetics 2016, 99(2):489-500.

166. Wallmeier J, Al-Mutairi DA, Chen CT, Loges NT, Pennekamp P, Menchen T, Ma L, Shamseldin HE, Olbrich H, Dougherty GW et al: Mutations in CCNO result in congenital mucociliary clearance disorder with reduced generation of multiple motile cilia. Nature genetics 2014, 46(6):646-651.

167. Watson CM, Crinnion LA, Morgan JE, Harrison SM, Diggle CP, Adlard J, Lindsay HA, Camm N, Charlton R, Sheridan E et al: Robust diagnostic genetic testing using solution capture enrichment and a novel variant-filtering interface. Human mutation 2014, 35(4):434-441. 


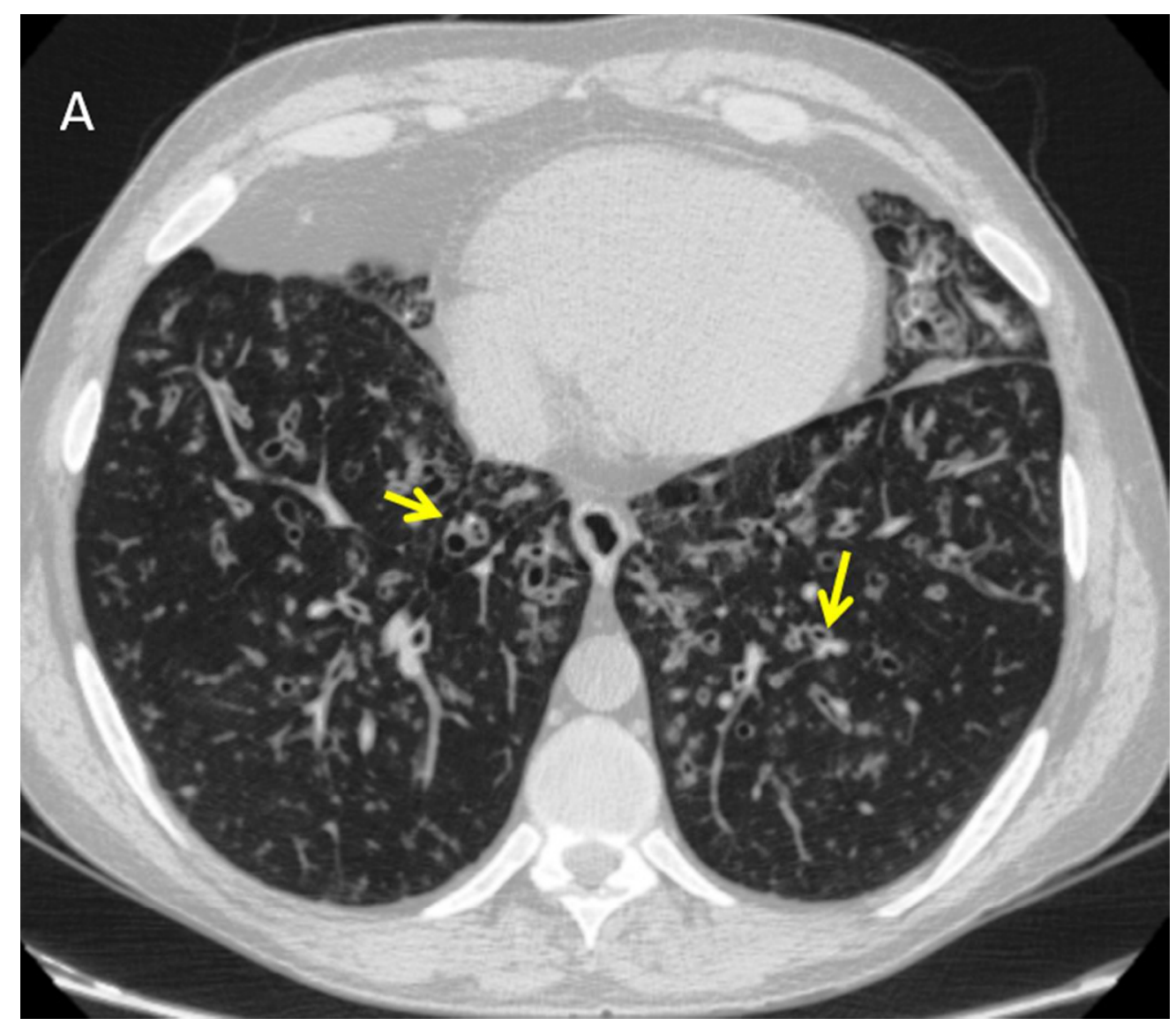

Rx typical findings in a patient with PCD: Bilateral bronchiectasis (arrows) 


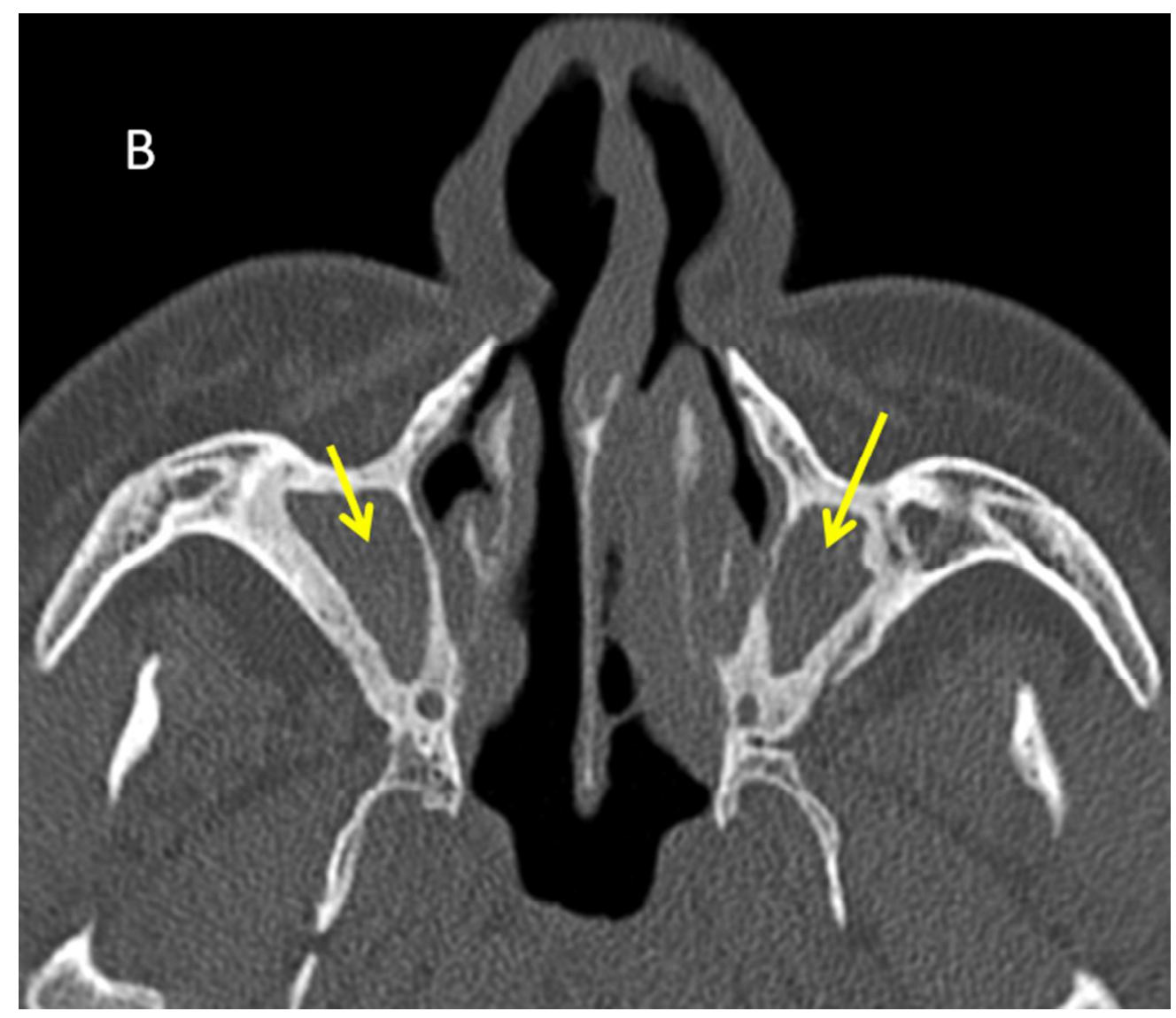

Rx typical findings in a patient with PCD: Hypoplasia of the maxillary sinuses and sinusitis (arrows)

3

4

5

7

8

9

10

11

12

13

14

15

17

18

19

20

21

22

23

24

25

26

27

28

29

30

31

32

33

34

35

36

37

38

39

40

41

42

43

44

45

46

47

48

49

50

51

52

53

54

55

56

57

58

59

60 


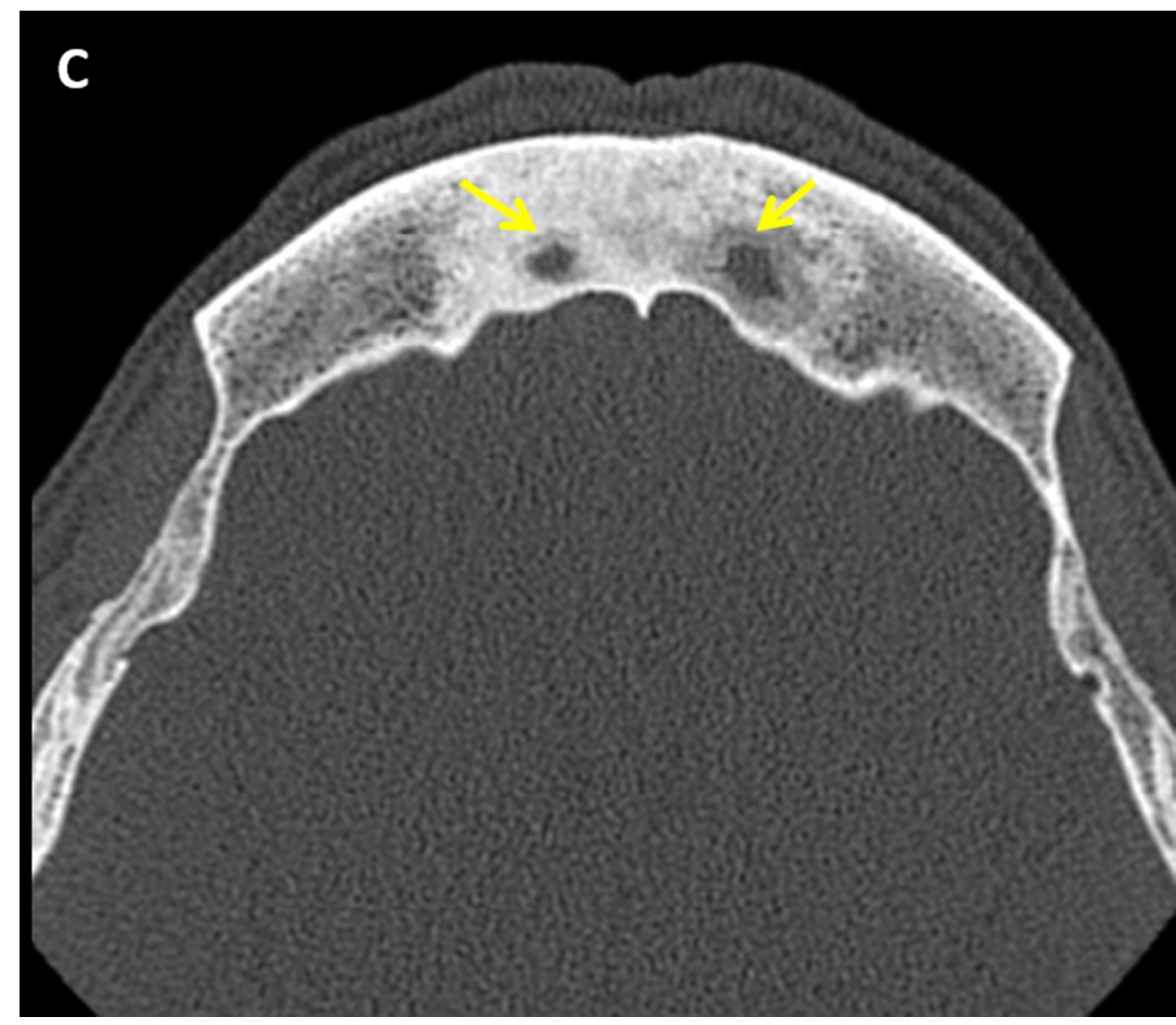

Rx typical findings in a patient with PCD: Aplasia of the frontal sinuses (arrows) 


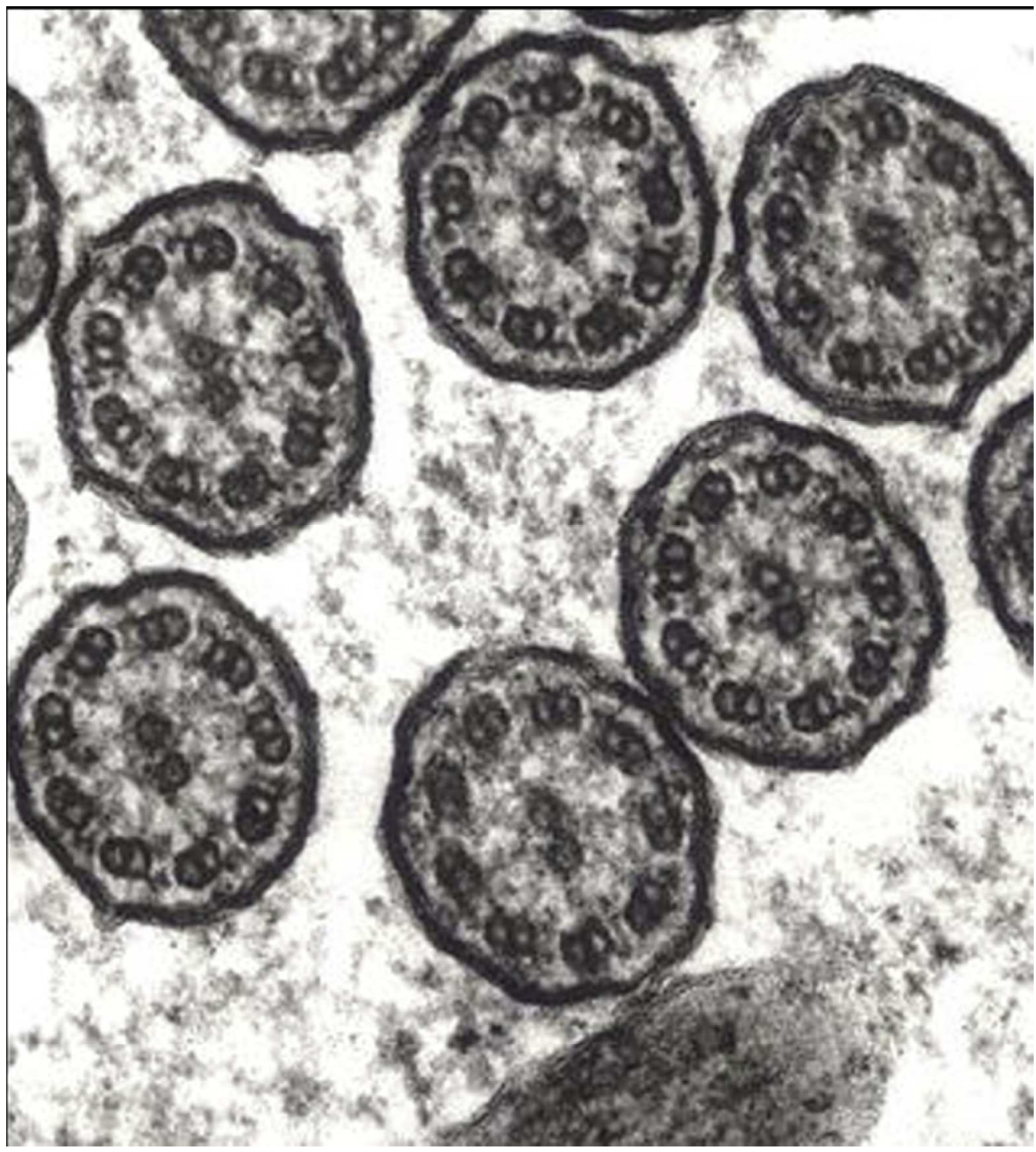

Figure 2A: Representative transmission electron microcopy picture of normal cilia ultrastructure. 
Figure 2A: Representative transmission electron microscopy picture of Primary Ciliary Dyskinesia dynein arms defects. 


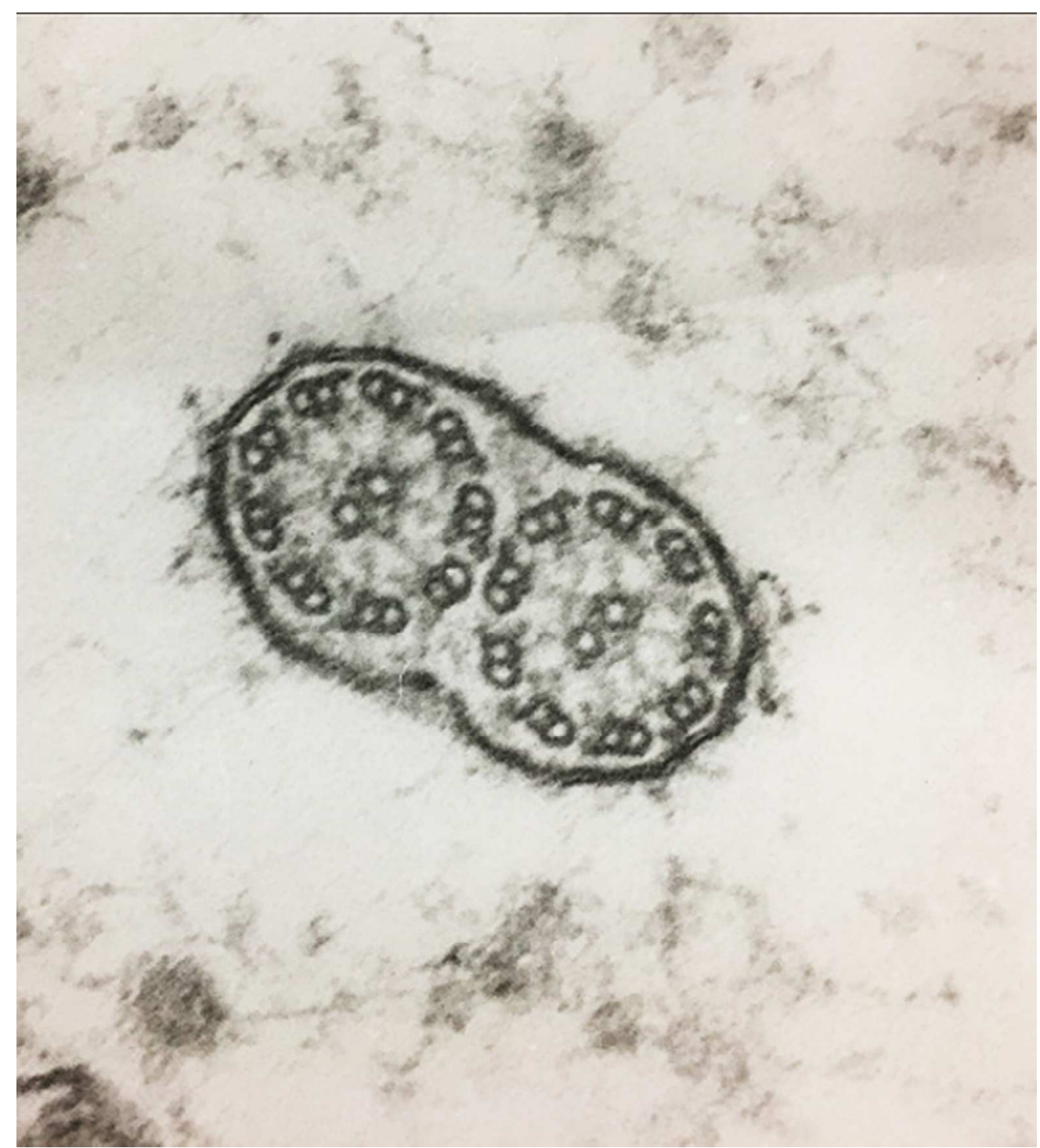

Figure 2C: Representative transmission electron microscopy picture of a cilia complex due to secondary defects, with normal ultrastructure in each cilia. 


\begin{tabular}{|c|c|}
\hline Organ & Clinical manifestation \\
\hline \multirow{3}{*}{ Lung } & Neonatal respiratory distress \\
\hline & Recurrent infections \\
\hline & Bronchiectasis \\
\hline \multirow{3}{*}{ Ear } & Secretory otitis media \\
\hline & Chronic otitis media \\
\hline & Hearing loss \\
\hline \multirow[b]{2}{*}{ Fossae and sinuses } & Chronic sinusitis \\
\hline & $\begin{array}{l}\text { Hypoplasia of sinuses, especially the } \\
\text { frontal }\end{array}$ \\
\hline \multirow{2}{*}{ Genital-urinary tract } & Male infertility \\
\hline & Female: reduced fertility \\
\hline \multirow[t]{2}{*}{ Organic laterality } & Situs inversus totalis \\
\hline & Situs ambiguus (heterotaxia) \\
\hline Central nervous system & Hydrocephalus (extremely rare) \\
\hline
\end{tabular}

URL: http://mc.manuscriptcentral.com/eood Email: Claire.Attwood@informa.com 
Dear reviewers, we appreciate your feedback and believe that the suggested changes have been helpful in order to improve the review.

\section{Editorial Comments}

1. Please confirm that your figures / tables are original and have not previously been published, OR, provide a copy of permission to use.

All authors confirm that figures and tables are original and have not previously been published.

2. Please provide a few reference annotations $\left({ }^{*}=\right.$ of importance, ${ }^{* *}=$ of considerable importance), followed by a brief sentence explaining why the reference is considered to be of interest.

Reference annotations including why they are considered to be of interest are included in the text. Changes are highlighted in yellow.

Referee(s)' Comments to Author:

Referee: 1

Comments to the Author

The authors have made a number of changes in this revised manuscript. As a result, the clarity and depth of the manuscript have been improved. There are a few minor issues remaining:

1. PAGES 8-9: The difference between screening tests and diagnostic tests for PCD needs further clarification. The authors added a statement that nasal NO cannot be used as a diagnostic test because of the association of false positives and false negatives, but false negative and false positive results are also a major problem for transmission electron microscopy, which is listed as a diagnostic tool. This remains a confusing point. It would be helpful if the authors stated their recommended scheme for PCD diagnosis, perhaps in the Expert Opinion section of the paper.

According to the last European Respiratory Society Task Force recommendations, we decided to include nNO levels into the diagnostic pathway (page 8). We also clarified that few PCD patients have normal levels, and low nNO levels are also associated with other similar pathologies as Cystic Fibrosis. Moreover, nNO levels cannot be measured in young children.

We also included a recommended scheme for PCD diagnosis in the Expert Opinion Section of the paper: "To diagnose PCD patients, having a strong clinical history (including nNO levels if it is possible), the starting point is HSVM analysis of the ciliary function, followed by TEM analysis of the ciliary structure. In case of poor health of the initial sample, ALI primary cultures of nasal or bronchial epithelial cells can be done, and ciliary function and structure re-analysed in order to differentiate primary from secondary defects. Sometimes it is necessary to repeat the sampling and tests, especially the motility studies. These tests are complex and it is essential that the studies are carried out by experts".

Changes are highlighted in yellow.

2. PAGE 13, TABLE 2: The authors twice state on page 13 that there are 35 PCD genes, but Table 2 now has 38 genes plus an empty line with a reference for Ak7, which would presumably bring the total to 39 . The numbers need to be updated, and the empty line in the table needs to be completed.

Reviewer is right, in the final version uploaded AK7 line was removed and we didn't notice it. Now is completed and highlighted in yellow. The number of genes is also changed to 39 in the text, and changes are also highlighted in yellow.

3. FIGURE 2B: It would help the reader if the authors added arrows pointing to the dynein arm defects in the axonemes. 
We agree with the reviewer. Now, arrows have been added to figure 2B pointing some dynein arm defects.

5

6

7

8

9

10

11

12

13

14

15

16

17

18

19

20

21

22

23

24

25

26

27

28

29

30

31

32

33

34

35

36

37

38

39

40

41

42

43

44

45

46

47

48

49

50

51

52

53

54

55

56

57

58

59

60

URL: http://mc.manuscriptcentral.com/eood Email: Claire.Attwood@informa.com 


\section{PUBLISHING AGREEMENT}

This is an agreement under which you, the author, assign copyright in your article to Informa UK Limited registered in England under no. 1072954 trading as Taylor \& Francis Group, Registered Office: 5 Howick Place, London SW1P 1WG (hereinafter 'Taylor \& Francis') to allow us to publish your article, including abstract, tables, figures, data, and supplemental material hosted by us, as the Version of Record (VoR) in the Journal for the full period of copyright throughout the world, in all forms and all media, subject to the Terms \& Conditions below.

Please read this agreement carefully, complete it, and return a copy to us by email, fax, or hard copy immediately, to avoid any delay in the publication of your article.

Postal address: Taylor \& Francis Journals Production, 4 Park Square, Milton Park, Abingdon OX14 4RN, UK

Fax: +44 (0) 2070176336 Email: T\&Fproduction@tandf.co.uk

\section{ARTICLE TITLE: ('Article') \\ AUTHOR(S): \\ JOURNAL TITLE: Expert Opinion on Orphan Drugs ('Journal') \\ Please complete and sign below.}

\section{Please tick either box A or box B, BUT NOT BOTH}

A I own copyright, and I am assigning copyright in my article to Taylor \& Francis. In the case of a multi-authored article, I confirm that I am authorized by my co-authors to make this assignment as their agent on their behalf. The co-authors have agreed the priority of the assertion of copyright and the order of names in the publication of the article.

ㅁ B I am a civil servant or an employee of a Government, Government Agency, International Organization, or Commercial Corporation which is granting a non-exclusive licence to publish the article and which hereby recognizes Taylor \& Francis as the sole licensee for the publication of the final, definitive, and citable Version of Record (VoR). In the case of a multi-authored article, I confirm that I am authorized by my co-authors to enter into this licence as their agent on their behalf. The co-authors have agreed the priority of the assertion of copyright and the order of names in the publication of the article.

If you have ticked B, please indicate which of the statements below apply to you (and your co-authors):

I am an employee of the UK, Canadian, Australian, or another Commonwealth Realm Government, and the Crown retains and asserts copyright.

ㅁ. I am a US Government (including NIH) employee and there is no copyright to transfer.

- I am a contractor of the US Government (includes NIH contractors) under contract number:

․ I am an employee of the European Commission and copyright is asserted and retained by the European Union.

I am an employee of the World Bank and copyright is asserted and retained by that entity.

I am an employee of the Food \& Agricultural Organization and copyright is asserted and retained by that entity.

I am an employee of a Government, Agency, or International Organization and copyright is retained by that entity. Name of entity:

I am employed and the copyright belongs to my employer (or is a 'work made for hire' under US law). Name of corporation:

\section{ASSIGNMENT OF COPYRIGHT}

I hereby assign Taylor \& Francis with full title guarantee all rights of copyright and related publishing rights in my article, in all forms and all media (whether known at this time or developed at any time in the future) throughout the world, in all languages, where our rights include but are not limited to the right to translate, create adaptations, extracts, or derivative works and to sublicense such rights, for the full term of copyright (including all renewals and extensions of that term), to take effect if and when the article is accepted for publication.

I confirm that I have read and accept the full Terms \& Conditions below including my author warranties, and have read and agree to comply with the Journal's policies on peer review and publishing ethics.

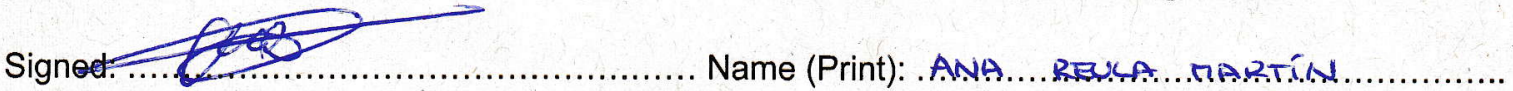

Position: .......Corresponding auther.......... Date: .....61.4.1.2017.

THIS FORM IS A LEGALLY BINDING DOCUMENT. WE RECOMMEND THAT YOU RETAIN A COPY OF IT AND CONSULT A LEGAL ADVISOR IF YOU HAVE ANY QUESTIONS. 


\section{ASSIGNMENT OF COPYRIGHT: TERMS \& CONDITIONS DEFINITION}

1. Your article is defined as comprising (a) your Accepted Manuscript (AM) in its final form; $(b)$ the final, definitive, and citable Version of Record (VoR) including the abstract, text, bibliography, and all accompanying tables, illustrations, data, and media; and $(c)$ any supplemental material hosted by Taylor \& Francis. This the sole understanding between you and us ('agreement'); no amendment, addendum, or other communication will be taken into account when interpreting your and our rights and obligations under this agreement, unless amended by a written document signed by both of us.

\section{TAYLOR \& FRANCIS' RESPONSIBILITIES}

2. If deemed acceptable by the Editors of the Journal, we shall prepare and publish your article in the Journal. We may post your accepted manuscript in advance of the formal publication of the VoR. We reserve the right to make such editorial changes as may be necessary to make the article suitable for publication, or as we reasonably consider necessary to avoid infringing third-party rights or as we reasonably consider necessary to avoid infringing third-party rights or
breaching any laws; and we reserve the right not to proceed with publication for whatever reason.

3. Taylor \& Francis will deposit your Accepted Manuscript (AM) to any designated institutional repository including PubMedCentral (PMC) with which Taylor \& Francis has an article deposit agreement; see 4 iv (a) below.

\section{RIGHTS RETAINED BY YOU AS AUTHOR}

4. These rights are personal to you, and your co-authors, and cannot be transferred by you to anyone else. Without prejudice to your rights as author set out below, you undertake that the fully reference-linked VoR will not be published elsewhere without our prior written consent. You assert and retain the following rights as author(s):

i. The right to be identified as the author of your article, whenever and wherever the article is published, such rights including moral rights arising under $\$ 77$, Copyright, Designs \& Patents Act 1988, and, so far as is legally possible, any corresponding rights we may have in any territory of the world.

ii. The right to retain patent rights, trademark rights, or rights to any process, product or procedure described in your article.

iii. The right to post and maintain at any time the Author's Original Manuscript (AOM; your manuscript in its original and unrefereed form; a 'preprint').

iv. The right to post at any time after publication of the VoR your AM (your manuscript in its revised after peer review and accepted for publication form; a 'postprint') as a digital file on your own personal or departmental website, provided that you do not use the VoR published by us, and Website, provided that you do not use the VoR published by us, and
that you include any amendments or deletions or warnings relating to the
article issued or published by us; and with the acknowledgement: 'The Version of Record of this manuscript has been published and is available in <JOURNAL, TITLE> < date of publication> http://www.tandfonline.com/ $<$ Article DOI>.

a) Please note that embargoes apply with respect to posting the $A M$ to an institutional or subject repository. For further information see our list of journals with applicable embargo periods: PDF' | Excel. published paper, the VoR published by us to any site, unt the final been published as Open Access on our website.

b) If, following publication, you or your funder pay an Article Publishing Charge for retrospective Open Access publication, you may then opt for one of three licences: CC BY, CC BY-NC, or CC BY-NC-ND; if you do not respond, we shall assign a $\mathrm{CC}$ BY licence. All rights in the article will revert to you as author.

v. The right to share with colleagues copies of the article in its published form as supplied to you by Taylor \& Francis as a digital eprint or printed reprint on a non-commercial basis.

vi. The right to make printed copies of all or part of the article on a noncommercial basis for use by you for lecture or classroom purposes provided that such copies are not offered for sale or distributed in any systematic way, and provided that acknowledgement to prior publication in the Journal is given

vii. The right, if the article has been produced within the scope of your employment, for your employer to use all or part of the article internally within the institution or company on a non-commercial basis provided that acknowledgement to prior publication in the Journal is given.

viii. The right to include the article in a thesis or dissertation that is not to be published commercially, provided that acknowledgement to prior publication in the Journal is given.

ix. The right to present the article at a meeting or conference and to distribute printed copies of the article to the delegates attending the meeting provided that this is not for commercial purposes and provided that acknowledgement to prior publication in the Journal is given.

$x$. The right to use the article in its published form in whole or in part without revision or modification in personal compilations, or other publications of your own work, provided that acknowledgement to prior publication in the your own work, p
Journal is given.

$x i$. The right to expand your article into book-length form for publication provided that acknowledgement to prior publication in the Journal is made explicit (see below). Where permission is sought to re-use an article in a book chapter or edited collection on a commercial basis a fee will be due, payable by the publisher of the new work. Where you as the author of the article have had the lead role in the new work (i.e., you are the author of the new work or the editor of the edited collection), fees will be waived. Acknowledgement to prior publication in the Journal should be made explicit (see below):

Acknowledgement: This <chapter or book> is derived in part from an article published in <JOURNAL TITLE> <date of publication> <copyright Taylor \& Francis>, available online: http:ll www.tandfonline.com/ <Article DOl>

If you wish to use your article in a way that is not permitted by this agreement, please contact permissionrequest@tandf.co.uk

\section{WARRANTIES MADE BY YOU AS AUTHOR}

5. You warrant that:

i. All persons who have a reasonable claim to authorship are named in the article as co-authors including yourself, and you have not fabricated or misappropriated anyone's identity, including your own.

ii. You have been authorized by all such co-authors to sign this agreement as agent on their behalf, and to agree on their behalf the priority of the assertion of copyright and the order of names in the publication of the article.

iii. The article is your original work, apart from any permitted third-party copyright material you include, and does not infringe any intellectual property rights of any other person or entity and cannot be construed as plagiarizing any other published work, including your own published work.

iv. The article is not currently under submission to, nor is under consideration by, nor has been accepted by any other journal or publication, nor has been previously published by any other journal or publication, nor has been assigned or licensed by you to any third party.

v. The article contains no content that is abusive, defamatory, libellous, obscene, fraudulent, nor in any way infringes the rights of others, nor is in any other way unlawful or in violation of applicable laws.

vi. Research reported in the article has been conducted in an ethical and responsible manner, in full compliance with all relevant codes of experimentation and legislation. All articles which report in vivo experiments or clinical trials on humans or animals must include a written statement in the Methods section that such work was conducted with the formal approval of the local human subject or animal care committees, and that clinical trials have been registered as applicable legislation requires.

vii. Any patient, service user, or participant (or that person's parent or legal guardian) in any research or clinical experiment or study who is described in the article has given written consent to the inclusion of material, text or image, pertaining to themselves, and that they acknowledge that they cannot be identified via the article and that you have anonymized them and that you do not identify them in any way. Where such a person is deceased, you warrant you have obtained the written consent of the is deceased, you warrant you have
deceased person's family or estate.

viii. You have complied with all mandatory laboratory health and safety procedures in the course of conducting any experimental work reported in your article; your article contains all appropriate warnings concerning any specific and particular hazards that may be involved in carrying out experiments or procedures described in the article or involved in instructions, materials, or formulae in the article; your article includes explicitly relevant safety precautions; and cites, if an accepted Standard or

Code of Practice is relevant, a reference to the relevant Standard or Code.

x. You have acknowledged all sources of research funding, as required by have arising from the direct applications of your research.

$x$. You have obtained the necessary written permission to include material in your article that is owned and held in copyright by a third party, which shall include but is not limited to any proprietary text, a third party, which other material, including data, audio, video, film stills, screenshots, musical notation and any supplemental material.

xi. You have read and complied with our policy on publishing ethics.

xii. You have read and complied with the Journal's Instructions for Authors.

xiii. You will keep us and our affiliates indemnified in full against all loss, damages, injury, costs and expenses (including legal and other professional fees and expenses) awarded against or incurred or paid by us as a result of your breach of the warranties given in this agreement.

xiv. You consent to allowing us to use your article for marketing and

\section{GOVERNING LAW}

6. This agreement (and any dispute, proceeding, claim or controversy in relation to it) is subject to English law and the parties hereby submit to the exclusive jurisdiction of the Courts of England and Wales. 